ACCESS TO HEALTH CARE FOR PRECARIOUS IMMIGRATION STATUS PERSONS: HUMAN FIRST, STATUS LATER

\author{
by \\ Tehmina Naseem, BA, York University, 2015 \\ A Major Research Paper \\ presented to Ryerson University \\ in partial fulfillment of the requirements for the degree of \\ Master of Arts \\ in the Program of \\ Immigration and Settlement Studies
}

Toronto, Ontario, Canada, 2016

(C) Tehmina Naseem, 2016 


\section{AUTHOR'S DECLARATION FOR ELECTRONIC SUBMISSION OF A MAJOR RESEARCH PAPER (MRP)}

I hereby declare that I am the sole author of this Major Research Paper. This is a true copy of the MRP, including any required final revisions, as accepted by my examiners.

I authorize Ryerson University to lend this MRP to other institutions or individuals for the purpose of scholarly research.

I further authorize Ryerson University to reproduce this MRP by photocopying or by other means, in total or in part, at the request of other institutions or individuals for the purpose of scholarly research.

I understand that my MRP may be made electronically available to the public.

Tehmina Naseem 


\title{
ACCESS TO HEALTH CARE FOR PRECARIOUS IMMIGRATION STATUS PERSONS: HUMAN FIRST, STATUS LATER
}

\author{
Tehmina Naseem \\ Master of Arts, 2016 \\ Immigration and Settlement Studies \\ Ryerson University
}

\begin{abstract}
This research paper seeks to understand the relationship between an individual's legal status and their access to Canada's healthcare system. The level of access of non-citizens to health care in Canada is determined by an individual's immigration status. Refugees, asylum seekers, temporary foreign workers, and permanent residents are four classes of immigrants that have access to specific health care policies depending on their legal status. Refugees and asylum seekers are eligible under the federal government's Interim Federal Health Care Program (IFHP) which provides them with access - although limited - to healthcare services in Canada. Conversely, there is not a federal or provincial health care policy that legally provides undocumented migrants with a right to access healthcare without any repercussions. The analysis of policies will reveal the current discourse surrounding citizenship status, legality, and human rights, in addition to the role of the state in exercising power over certain bodies.
\end{abstract}

Key words: precarious immigration status; Canada; healthcare policies; undocumented immigrants; biopower; human rights 


\section{Table of Contents}

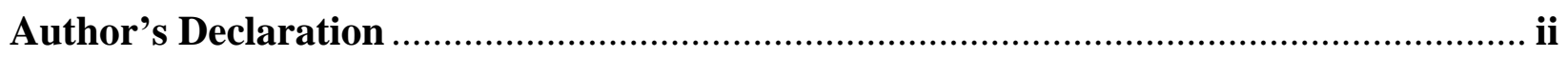

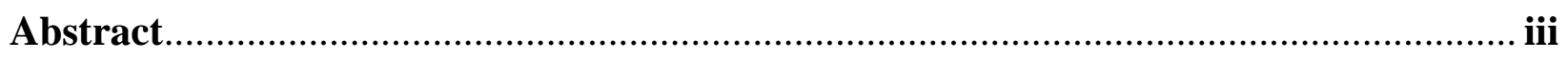

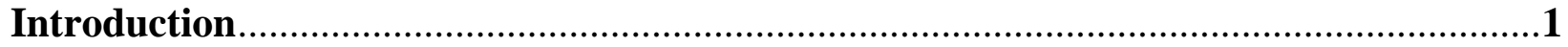

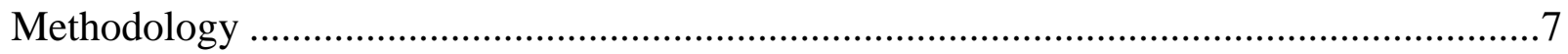

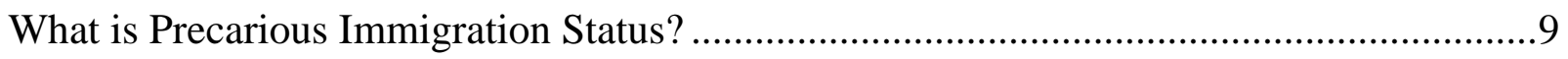

Who is an Undocumented Immigrant?...........................................................................11

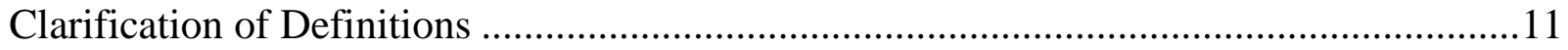

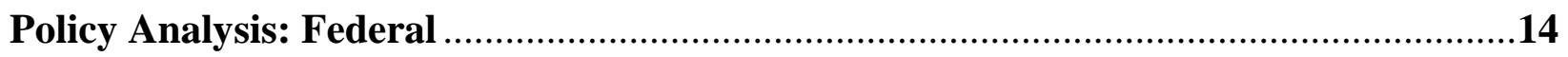

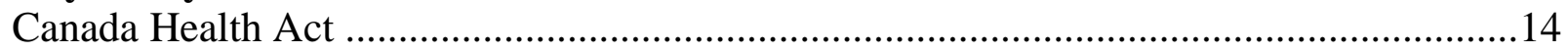

Canada Health Act Annual Report, 2014-2015: What does the CHA Report Indicate? .....16

The Interim Federal Healthcare Program ........................................................................... 18

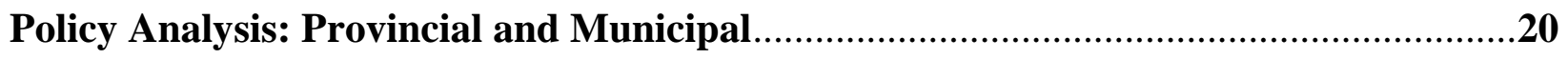

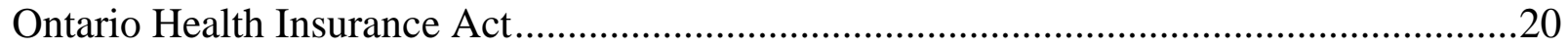

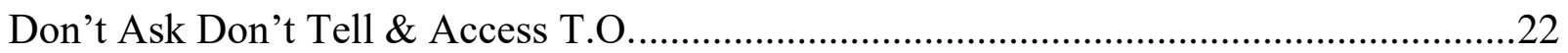

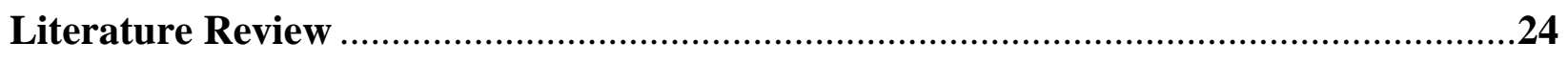

Authors' Main Arguments: Status and Access to Health Care ……………………...........24

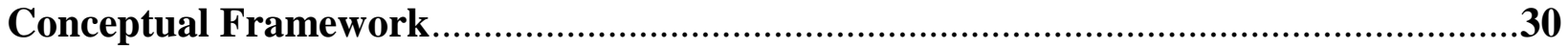

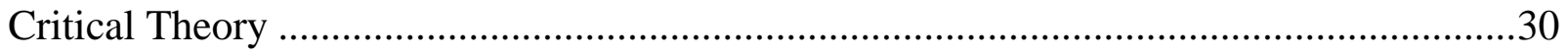

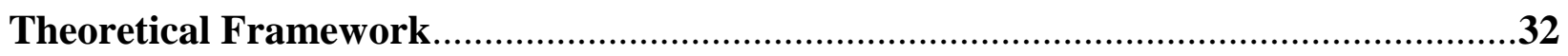

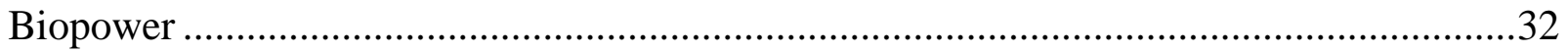

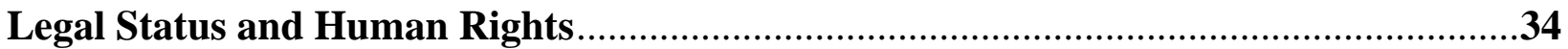

IFHP Federal Court Decision: Human Rights and Sovereign Power ...................................36

IFHP Federal Court Decision: Why were the 2012 Cuts Overruled? ....................................40

IFHP Federal Court Decision: What Would Foucault Say? ...............................................4

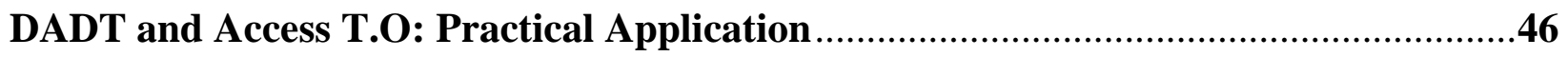

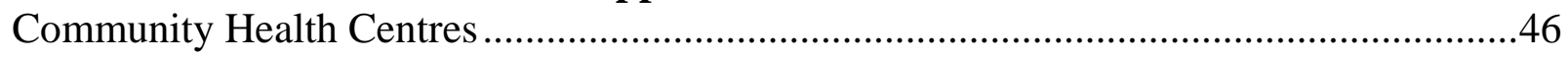

Non-Compliance of TPS and Its Implications on Undocumented Immigrants ...................49

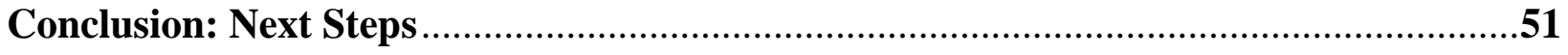

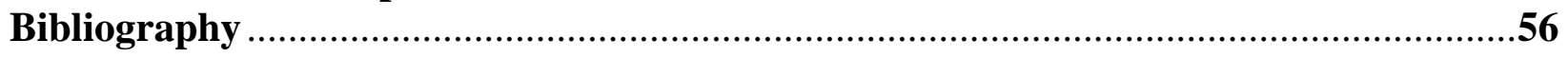




\section{Introduction}

How does an individual's immigration status determine their level of access to Canada's health care system? This research paper seeks to understand the relationship between an individual's legal status and their access to Canada's healthcare system. The level of non-citizens' access to health care in Canada is determined by an individual's immigration status. Refugees, asylum seekers, temporary foreign workers, and permanent residents are four classes of immigrants that have access to specific health care policies depending on their legal status. Refugees and asylum seekers are eligible under the federal government's Interim Federal Health Care Program (IFHP) which provides them with access - although limited - to healthcare services in Canada. Conversely, there is not a federal or provincial health care policy that legally provides undocumented immigrants with a right to access healthcare without any repercussions such as deportation (Campbell, Klei, Hodges, Fisman, \& Kitto, 2012).

In addition to the limitations and barriers for refugees and asylum seekers in Canada, it is important to note that Canada is a party to multiple international treaties in which health is deemed as a basic human right (Heymann, Cassola, Raub, \& Mishra, 2013). Thus, the analysis of policies will reveal the current discourse surrounding citizenship status, legality, and human rights, in addition to the role of the state in exercising power over certain bodies. This paper examines the normative and institutional framework by exploring policies that have been implemented and the limitations in their application. Furthermore, factors are explored that prevent precarious immigration status individuals from accessing health care services available to them. Ultimately, this research shows that the current situation in Canada is contrary to Canada's Charter and Canada's international human rights obligations. It reveals the contradiction between Canada's human rights obligations pertaining to healthcare under international legal instruments and the 
current implementation of its healthcare policies. Thus, the context of the paper presents the legislative complexity with different levels of jurisdiction for different groups of migrants and the levels of access they are provided to healthcare. Moreover, Foucault's theory of biopower is used to examine the power relations between a state and its people whereby determining the type of health care an individual receives is an exercise of power over one's body. This theory further explores the rhetoric of securitization as the nation state exercises its power over certain bodies of people by deeming their life as less valuable than others.

Moreover, this research paper briefly undertakes a top-down approach beginning from the federal to the provincial and municipal aspects of Canadian government in relation to immigration status, healthcare policies, and human rights. This paper contributes to the already existing literature illuminating the importance of human rights for precarious status migrants. It provides additional knowledge of ongoing issues surrounding limitations and barriers in the current policies of Canada with an emphasis on the state's obligations to the international human rights framework. In doing so, the gaps and limitations presented in the policies and their practical application demands the recommendations that can reduce the barriers for precarious status migrants. The policy analysis allows for social movements, activists, political leaders, and future researchers in academe to continue to explore the importance of human rights for migrants in Canada. Furthermore, it enables people to develop possible routes for changes in policies and/or implementation of better programs provided to precarious immigration status individuals.

Thus, a policy analysis beginning with the federal government's Canada Health Act (CHA) and the IFHP will be important in understanding the legal terminology as well as limitations for certain groups of people depending on their legal status. The Canada Health Act (CHA) was established to develop a relationship between the federal and the provincial governments of 
Canada pertaining to cash contributions (CHA, 1985, c. C-6, s.2). The CHA begins by explaining the importance of Canadians achieving improvements in their lifestyle through healthy choices that include fitness and prevention of disease (CHA, 1985, c. C-6). Furthermore, the Act seeks to promote a system of healthcare services whereby individuals are able to maintain their physical and mental health and that citizens are able to access quality healthcare without facing any financial barriers (CHA, 1985, c. C-6, s.3).

Thereafter, the second policy of analysis within the federal government known as the Interim Federal Health Program (IFHP) will be discussed. It was established in 1957 for humanitarian reasons to provide eligible non-citizens with essential preventative and emergency medical services (Canadian Healthcare Association, 2012). The main purpose for the IFHP is to provide temporary coverage to refugees, refugee claimants/asylum seekers, rejected refugee claimants (until their date of deportation), and other individuals that are detained under the Immigration and Refugee Protection Act (IRPA) (CIC, 2016a). They are provided temporary coverage during the time that they are ineligible under any provincial or territorial health insurance plan (CIC, 2016a).

The federal government of Canada had implemented drastic changes to the IFHP in 2012 which resulted in a federal court case pertaining to human rights violations. The Canadian Doctors for Refugee Care v. Canada, 2014 will be used as a case study which will be analyzed in two parts to understand the human rights framework. Firstly, a brief analysis of CDRC v. Canada, 2014 will seek to reveal the debate between sovereignty and human rights in which it will be argued that human rights should prevail sovereign power. Secondly, the case will explore the judge's decision which overruled the federal government's IFHP cuts. In this case, two of the several reasons for 
the judge's decision will be discussed in support of the human rights framework with the argument that an individual's immigration status should not determine their level of access to healthcare.

The provincial and municipal focus is narrowed down to one province and one city due to the limited scope of this paper. Thus, the provincial health care policies of Ontario will be briefly explored including the Ontario Health Insurance Act known as Regulation 552 which outlines the eligibility criteria for the Ontario Health Insurance Program (OHIP). In addition, the policies in the municipality of Toronto will be explained as it is Canada's first sanctuary city for undocumented immigrants (McKeown, 2013). Toronto has made considerable progress in its policies targeting precarious immigration status individuals in receiving publicly funded services such as healthcare. The policies including “Access without Fear: Don’t Ask Don’t Tell” and "Access T. O" will be further examined to understand the support that Toronto is providing to uninsured individuals and the barriers or limitations they face in accessing healthcare services. The Don't Ask Don't Tell (DADT) campaign was implemented in Toronto as an informal policy whereby city staff could provide their services without asking a client/patient about their immigration status (No One is Illegal-Toronto, 2004b). The campaign was launched in 2004 by No One is Illegal-Toronto which enabled individuals without a legal status to access city services without the fear of being incarcerated or deported (No One is Illegal-Toronto, 2004b).

The different levels of access to health care based on different migration statuses are contrary to the Canadian Charter of Rights and Freedoms and international human rights instruments. A person's eligibility criteria under certain health acts should not be solely based on their legal status. A permanent resident will have a better quality of life than an undocumented immigrant due to the fact that their being human was not enough for the healthcare services to be provided. Instead, their status as permanent resident and as 'non-status' places them on either end 
of a spectrum. Canada adheres to the Universal Declaration of Human Rights (UDHR) and is a party to the international human rights instruments, including the International Covenant on Economic, Social and Cultural Rights (ICESCR) (United Nations, Vol. 993). The right to health is described under Article 12 of the ICESCR as "the enjoyment of the highest attainable standards of physical and mental health" (United Nations, Vol. 993, article 12). Although the right to health does not equate to 'access to health care', the World Health Organization (WHO) recognizes the right to health care as freedoms and entitlements whereby one has the freedom to control their body, and the entitlement to equal opportunities to health protection (Committee on Economic, Social, and Cultural Rights, 2009).

On the contrary, it can be understood that one's access to health care is determined by the facilitation of services and resources by a nation state in providing those opportunities. Therefore, Canada's compliance with the rights and principles set forth in the human rights instruments such as the ICESCR presumptively indicates Canada's obligations to providing the right to health care. Article 2 of the ICESCR conveys the right to healthcare to which Canada should be obligated, however, as will be discussed in the paper below, it is evident that access to that right is greatly limited for migrant populations. To explain, Article 2 outlines that each state party including Canada must "take steps...to the maximum of its available resources, with a view to achieving progressively the full realization of the rights recognized" (United Nations, Vol. 993, s. 2.1) Furthermore, it illustrates the obligation of State Parties to "guarantee that the rights enunciated...will be exercised without discrimination of any kind as to... political or other opinion, national or social origin, property, birth or other status" (United Nations, Vol. 993, s. 2.2)

Canada's current healthcare policies present the contradiction between its obligations to the international human rights instruments and the actions taken by the state whereby differential 
treatment of different migrant groups continues to exist. Although Canada, as a State Party, should take steps to ensure the rights of its people without discriminating against their status, it is evident that the current implementation of healthcare policies embedded in the discourse of securitization do not guarantee these rights.

Additionally, the Committee on Economic, Social, and Cultural Rights (CESCR) monitors the independent State Parties including Canada in their implementation of the ICESCR (Office of the United Nations High Commissioner for Human Rights, 2016). In a recent report pertaining to Canada's human rights obligations, the committee expresses its concern towards Canada's denial of access to health care for undocumented immigrants (CESCR, 2016, s.49). Thus, the committee recommends that Canada ensure equal access to the IFHP for migrant populations despite their immigration status in line with Canada's human rights obligations (CESCR, 2016, s.50). This concern is evident in another report wherein the committee suggests that Canada decrease its security measures in regards to the detainment of undocumented and irregular migrants whilst also ensuring equal access to essential health care services "irrespective of their status" (CESCR, 2016, s.12). The reports written by the human rights committee and the CESCR portray the humanitarian approach by which Canada should be abiding in order to provide equal access to healthcare for migrants. Additionally, the reports indicate that Canada is not currently undertaking steps to ensure the health and safety of migrants including undocumented immigrants whose non-status separates them from the rest of the population.

Canada has contravened international human rights and it is indefinitely a legal matter as judicial decisions create precedent and oversee the state's exercise (or abuse) of power and the infringement upon peoples' freedoms and rights. The 2014 case of CDRC v. Canada presented an opportunity whereby individuals of precarious immigration statuses were inclined to expose the 
government's exercise of power over their bodies. As a result, the judge analyzed the actions of the federal government as well as taking into account the international human rights framework. Although the judge agreed that Canada's sovereignty limits the international human rights treaties and conventions from imposing their moral agenda, the judge nevertheless acknowledged the importance of maintaining Canada's moral obligation to human rights (CDRC v. Canada, 2014). In a nutshell, the Court stated that the Charter "should generally be presumed" to provide protection which does not fall below that provided by similar international human rights provisions (Reference Re Public Service Employee Relations Act, 1987, s.59). Furthermore, it stated that "various sources of international human rights law" may be "relevant and persuasive sources of interpretation of the Charter's provisions" (Reference Re Public Service Employee Relations Act, 1987, s.60). Moreover, it portrays that "Canada's international human rights obligations should inform not only the interpretation of the content of the rights guaranteed in the Charter, but also the interpretation of what can constitute pressing and substantial s.1 objectives" (Slaight Communications Inc. v. Davidson, 1989, s.4c).

\section{Methodology}

This research paper begins with the explanation of terms and concepts including precarious immigration status and undocumented immigrants. Thereafter, the federal, provincial, and municipal policies are analyzed to provide a normative and contextual framework of Canada's health care policies. Moreover, the paper continues with a review of existing literature on the topic of healthcare and legal status in Canada. The literature was gathered by inputting specific terms in order to find scholarly articles in the Ryerson University research database. These terms were not limited to, but included, 'health care', 'access', 'precarious status', 'Canada', 'barriers', 'policies', and 'human rights'. Several articles were made available with similar arguments surrounding 
Canada's healthcare system and its accessibility for precarious immigration status individuals. The terms were useful in finding articles that would present arguments about the barriers that different types of immigrants face in accessing healthcare in Canada, and the solutions that can be provided to minimize these barriers.

It is necessary to gather scholarly works on a topic of interest as the information can be applied to one's own research. These authors revealed important information pertinent to the topic of healthcare and legal status as they explained their research, limitations, methodologies, recommendations, and overall knowledge on the topic. In addition, the articles that have been selected for the literature review portray the importance of human rights and the acknowledgement of human rights which is immensely supported by this research paper. Following the literature review, Canada's human rights obligations are further discussed by examining the Federal Court case of Canadian Doctors for Refugee Care v. Canada, 2014 in order to understand the conflicting relationship between sovereign power and human rights. The Federal Court decision and the legal instruments including ICESCR and the Canadian Charter of Rights and Freedoms were utilized to analyze the sections that exhibit the underlying concept of human rights in relation to the case study. The case is used to discuss Canada's current denial of obligations to international human rights instruments but nonetheless portrays the positive contribution of the Canadian Charter.

The human rights argument is followed by the discussion of Toronto's municipal policies including DADT and Access T.O and their practical application. The practical application component of the research consisted of audits and reports written by non-profit agencies and/or organizations to expose the ongoing barriers faced by precarious immigration status individuals residing in Toronto. This section depicts the barriers faced by undocumented immigrants as well as healthcare practitioners and Community Health Centres (CHCs) in providing healthcare 
services. To explain briefly, CHCs were developed in Ontario to provide healthcare services for diverse populations facing barriers to equal access due to their low-income status, immigration status, mental health issues or addiction issues, and disabilities (Surani, 2013). They are governed by "community-elected boards comprised of clients, community members, health providers, and community leaders" (Surani, 2013). The primary care model of these organizations is to provide health care services to people without health cards (Surani, 2013). However, this section explores the ongoing support provided to non-status migrants by $\mathrm{CHCs}$ and the current barriers that are faced by CHCs in fulfilling their role.

Thereafter, the latter component of this section conveys the ongoing concern with the noncompliance of Toronto Police Services in following the DADT policy which exacerbates the vulnerability of undocumented immigrants. The examination of a recent report pertaining to the practices of the TPS reveals the active efforts made by the TPS to arrest and detain non-status individuals in Toronto. Thus, this section of the paper focuses on the problems associated with listing the TPS as an accessible service for undocumented immigrants as it creates false hope for the population seeking safety and security. Lastly, the paper concludes with an overview of the federal, provincial, and municipal policies implemented in Canada. There is further discussion pertaining to the barriers faced by migrant populations of precarious status in accessing healthcare due to their legal status which outlines the current debate surrounding human rights and sovereignty. The implementation of humanitarian policies such as IFHP and even municipal policies such as DADT and Access T.O outline the positive progress that Canada is making. However, the data gathered also shows that applying these policies is still difficult as there are several limitations faced by groups of migrants in a precarious status.

\section{What is Precarious Immigration Status?}


The groups of migrants considered as immigrants in a precarious situation for the purposes of this research paper include permanent residents in their three-month wait period, temporary foreign workers, refugees, asylum seekers/refugee claimants, and undocumented immigrants. Several authors make the argument that individuals with precarious immigration status continue to face barriers depending on their level of access to health care. Goldring, Berinstein, \& Bernhard (2009) state that a migrant with a precarious status may include anyone who is reliant upon a third party to remain in Canada, who does not have the right to remain in Canada permanently, and someone who needs work authorization. Campbell et al. define precarious status immigrants as individuals whose legal status is unstable (2012). Thus, groups of people such as refugee claimants/ asylum seekers, refugees, failed refugee claimants, temporary foreign workers and undocumented/non-status migrants fall within this category (Elgersma, 2008). However, it is also to be noted that a permanent resident may fall into precarious status as they may lose their status if they are unable to maintain their residency requirements (Goldring et al., 2009).

Brabant \& Raynault refer to precarious status immigrants as individuals who are born in a country other than Canada who do not have a legal status because they are not permanent (2012a). Their definition does not include refugees or asylum seekers as they have a legal status regardless of its precariousness. Nonetheless, different levels of access to health care are provided to individuals that are categorized within a different group of precarious status (Campbell et al., 2012). The most vulnerable group of people within this category remain non-status or undocumented migrants as they remain underground or hidden due to fear of law and/or immigration enforcement (Brabant \& Raynault., 2012b).

The article written by Goldring et al. provides an excellent summary to clarify the different subgroups belonging to "precarious immigration status" (2009). These distinctions amongst 
temporary foreign workers, sponsored family members, seasonal workers, failed refugee claimants, etc., are crucial in the introductory proponents of a research dealing with a topic that is largely understudied and hidden. The authors explained precariousness in much detail without necessarily implying the connotations to their non-status and the implications of such precariousness when accessing social or health care services. On the other hand, Campbell et al. explained the specific subgroups that belong in the term "precarious immigrant status" but further argued that undocumented migrants within this category face several barriers in comparison to refugees and permanent residents when accessing healthcare (2012).

\section{Who is an Undocumented Immigrant?}

The definition of "undocumented immigrant" has been explained in various studies seeking to understand the population's standard of living and quality of life. For example, one study noted that undocumented immigrants refer to people residing in a host country in which they do not have legal documents pertaining to their immigration status (Campbell et al., 2012). This includes people who entered Canada illegally, failed refugee claimants, people who were smuggled or trafficked, or those who legally entered Canada but did not respect the conditions on their visa requirements or overstayed their visit or used false documentation (Campbell et al., 2012). In another article, this population is identified as "non-status immigrants" including failed refugee claimants and immigrants who had legally entered Canada but lost their status due to unmet requirements including the expiration of their visa (Miklavcic, 2011). For example, residents who were previously allowed entry into Canada as live-in caregivers or temporary migrant workers may have failed to meet certain requirements that resulted in a loss of status (Brabant \& Raynault, 2012a).

\section{Clarification of Definitions}


For the purposes of this paper, the term 'precarious immigration status' will illustrate any individual residing in Canada that has a status which is unstable and capable of being revoked. The main focus of this paper is to explore the precariousness of a person's status which determines their access to health care and minimizes their human rights which pushes them to the margins of society. Thus, this paper will examine Canada's healthcare policies with special attention geared towards precarious immigration status individuals including refugees, refugee claimants/ asylum seekers, failed refugee claimants, temporary foreign workers, and undocumented immigrants. In addition, permanent residents will also be briefly discussed although they do not have a precarious immigration status.

A permanent resident is not considered a precarious status individual, however, they also require applications for renewal of their permanent residency (as a citizen does not), and they also have to comply with a three-month wait period before receiving a health card in Canada (Campbell et al., 2012). Therefore, permanent residents may not be as vulnerable as precarious immigration status persons, but they also face certain limitations and barriers to accessing healthcare due to their status. Under the Immigration and Refugee Protection Act (IRPA), a permanent resident is a foreign national who is admissible in Canada and who has met the obligations set out for permanent residency (IRPA, 2001, c.27, s.2). An individual with a precarious status is anyone whose legal status is not stable (Campbell et al., 2012). However, it can be argued that due to the three month wait period for permanent residents to access healthcare, they also remain in a precarious situation until that wait period is over.

A refugee in Canada is a protected person "whose application for protection has been finally determined by the Board to be a Convention refugee or to be a person in need of protection..." (IRPA, S.C. 2001, c.27, s.21). In addition, an asylum seeker is an individual that 
seeks asylum (Gagnon, 2002). They are also known as refugee claimants and they are allowed to reside in Canada on a temporary basis on humanitarian grounds until a final decision is reached on their claim (Gagnon, 2002). Refugee claimants or asylum seekers are individuals that have been deemed eligible to be referred to the Immigration and Refugee Board and await their determination by the Board (CIC, 2016a).

A rejected refugee claimant is a person whose claim for protection has been rejected or is not eligible for an appeal (CIC, 2016a). The level of access to health care provided to this population will be mostly examined during the analysis of federal policies including the IFHP since refugees, asylum seekers, and rejected refugee claimants are eligible under this program. An important distinction to make between ineligible refugee claimants and rejected refugee claimants is that an ineligible claimant is an individual whose claim for protection to the IRB is not accepted, but the individual is still eligible to apply for a Pre-Removal Risk Assessment (PRRA) (CIC, 2016a). The Canada Border Services Agency (CBSA) permits certain groups of people on an individual basis to apply for a PRRA if they are facing removal from Canada (CIC, 2016a). It is an opportunity for individuals facing removal to provide the authorities with a legitimate reason as to why returning to their country may result in danger or persecution (CIC, 2016a). On the other hand, a rejected refugee claimant has had their asylum claim rejected and they do not have any other options for an appeal and neither can they apply for a PRRA (CIC, 2016a). Two other groups of people that are eligible under the IFHP include victims of human trafficking, and detainees under the IRPA. The former is provided with coverage for the duration of their temporary permit whilst the latter is provided during their detainment (CIC, 2016b).

Finally, the most vulnerable group of precarious status immigrants are undocumented immigrants who do not have a legal right to reside in Canada (Magalhaes et al., 2010). For the 
purposes of this paper, undocumented immigrants will be used interchangeably with non-status individuals to avoid redundancy. This group will be defined as individuals who have entered Canada illegally, or,

“...appealed their denied refugee claim on humanitarian and compassionate grounds and had the appeal rejected and remain in the country after their removal date, or legally entered Canada and did not respect the conditions and terms of their visa or overstayed their visa..." (Campbell et al., 2012).

Undocumented immigrants are the least studied population in Canada and the most vulnerable group of people due to their non-status (Magalhaes et al., 2010). However, as it will be discussed below, the city of Toronto has implemented certain policies that promote the wellbeing and safety of undocumented individuals. Thus, this population's access to health care services will be further explored in the latter half of the research paper in order to acknowledge the positive change that has been provided and the steps that are being taken to eliminate current barriers and/or limitations.

\section{Policy Analysis: Federal}

\section{Canada Health Act}

The primary objective stated in the Canada Health Act health is to "protect, promote and restore the physical and mental well-being of residents of Canada to facilitate reasonable access to health services..." (CHA, 1985, c. C-6, s.3). It is interesting to note that Canadian citizens are the main priority for the CHA although it continues to promote a healthy lifestyle for each individual's wellbeing. The program criteria under the CHA covers five main proponents that make provinces eligible for cash contributions. These include: public administration, comprehensiveness, universality, portability, and accessibility (CHA, 1985, c. C-6, s.7). The two most noteworthy are universality and accessibility, as they indicate the universal application of healthcare services and 
reasonable access to insured residents (CHA, 1985, c. C-6, s.7). The definition of the term resident is as follows:

"in relation to a province, a person lawfully entitled to be or to remain in Canada who makes his home and is ordinarily present in the province, but does not include a tourist, a transient or a visitor to the province" (CHA, 1985, c. C-6, s.2).

Hence, the term universality as portrayed in the CHA becomes limited and applicable to any person who is defined as a resident. The promotion of a healthy lifestyle conveyed in the CHA applies only to those who are lawfully present in Canada and therefore, their lives are the only ones that are valued by the federal government. For example, the definition of a resident fails to be applicable to undocumented immigrants and therefore, the term universality which seeks to provide uniform healthcare services to all residents, becomes a term that is only meaningful for those whose lives are valued and protected under the CHA.

In addition, the term 'accessibility' indicates that each province must provide reasonable access to healthcare services by insured persons (CHA, 1985, c. C-6, s.12). 'Insured person' is defined as any individual that is legally entitled and insured by their provincial governments to receive healthcare in Canada (CHA, 1985, c. C-6, s.2). Accordingly, accessibility is an applicable term to those that are already privileged in their societies who are provided access to healthcare services based on their insurance and assumptively, their legal status. Therefore, the principle of accessibility highlighted in the CHA is thus relevant to those whose lives are protected by their secure legal status. Canadian citizens are able to access provincial/territorial healthcare coverage and permanent residents can access the same services once their three-month wait period is over (Campbell et al., 2012). 
However, refugees, asylum seekers, temporary foreign workers, rejected refugee claimants, and temporary residents are unable to access the same level of healthcare due to their precarious immigration status (Brabant \& Raynault, 2012a). Furthermore, the promotion of accessibility and reasonable access to health care in the CHA is inapplicable to undocumented immigrants because their non-status prevents them from obtaining insurance, and thus, access to services that can potentially save their lives (McKeown, 2013). These legal terms are important to consider as they indicate the limitations for one population over another. Although universality and accessibility seem to appear fair and just to any person reading the $\mathrm{CHA}$, it is to the extent that those whose bodies are valued are placed in positions that their statuses do not negatively impact their health.

\section{Canada Health Act Annual Report, 2014-2015: What does the CHA Report Indicate?}

The CHA Annual Report indicates whether or not provinces are upholding the federal government's principles including public administration, comprehensiveness, universality, portability, and accessibility in order to receive their cash contributions (Health Canada, 2015). The CHA annual report from 2015 illustrates each provincial and territorial health act indicating the eligibility criteria along with the terms and conditions for accessing healthcare services. The report begins with the statement, “...federal department responsible for helping people of Canada maintain and improve their health" (Health Canada, 2015). The term 'people of Canada' raises questions surrounding belongingness and inclusiveness. For example, 'people of Canada' may be interpreted as every human being residing on Canadian soil and therefore, deserving of Canadian services such as healthcare. However, the reality of this term oppositely indicates that "people of Canada' deserving of healthcare services are those whose statuses fit the criteria. 
The document further continues with the statement that, "Health Canada is committed to improving the lives of all of Canada's people..." (Health Canada, 2015). Once again, the terminology can be highly misinterpreted whereby perceiving the CHA as one that is inclusive of all individuals and generous to all people. However, the analysis thus far has revealed that there are limitations placed on certain groups of people depending on their citizenship or immigration status. Hence, the statement is in fact promoting the improvement of health for 'all of Canada's people' although those people mentioned are privileged residents with an eligible status.

In addition, the five principles that are mentioned including universality and accessibility are engrained in the federal health plan to promote "Canadian values of equity and solidarity" (Health Canada, 2015). However, the provincial and territorial governments responsible for applying the federal government's equitable and universal health care policy do not necessarily follow these moral guidelines. For example, Prince Edward Island and Newfoundland and Labrador do not deem refugees eligible under their provincial health acts (Health Canada, 2015). In other provinces and territories such as Nova Scotia and the Northwest Territories, refugees are eligible only after they receive permanent residency (Health Canada, 2015).

In Quebec and Ontario, refugees are eligible for healthcare services under their provincial acts and in Saskatchewan, they are eligible once they receive Convention refugee status (Health Canada, 2015). In Yukon, refugee claimants and convention refugees are both ineligible under their provincial act (Health Canada, 2015). In the remaining provinces including New Brunswick, Manitoba, British Columbia, and Nunavut, the term 'refugee' is not mentioned in their health policies at all (Health Canada, 2015). Other groups of immigrants including temporary workers, refugee claimants, foreign workers, and international students are mostly ineligible for medical insurance and non-status individuals are not even up for debate (Health Canada, 2015). 
Thus, the question remains: "who are 'Canada's people"”? If the federal government seeks to promote equity, universality, and accessibility, while hoping for a nation that maintains and improves its people's health, then some groups of individuals with different immigration statuses should not be excluded from health care policies. These statements are vague and seek to promote an equitable healthcare system for individuals whose bodies are of value based on their status (Genel, 2006). An 'asylum seeker' or an 'undocumented immigrant' is not provided the same access to healthcare services because they are defined by the government to be of a different value than 'permanent residents' and 'Canadian citizens'. Therefore, the powerful play on words not only misguides people in assuming that universal healthcare will be provided to all people, but that it will be provided to those who have a certain legal status. As Foucault and Agamben have argued, biopower and biopolitics discriminate between human beings by determining whose life is or is not an object of protection (Genel, 2006).

\section{The Interim Federal Healthcare Program}

Canada is a signatory to several United Nations conventions including the 1951 Convention Relating to the Status of Refugees and therefore has an "obligation to grant protection to Convention refugees and persons in need of protection (Olsen, El-Bialy, Mckelvie, Rauman, \& Brunger, 2014). Thus, the IFHP was established for humanitarian reasons to provide eligible noncitizens with essential preventative and emergency medical services (Canadian Healthcare Association, 2012). Basic coverage often includes similar coverage provided under provincial and territorial health plans, although the benefits received are not the same (CIC, 2016a). Supplemental coverage includes limited dental and vision care, access to services provided by healthcare practitioners including clinical psychologists or speech language therapists, and assistive devices and medical equipment such as insulin for diabetic patients, oxygen supplies, hearing aids, and/or 
orthopedic equipment (CIC, 2016a). Eligible beneficiaries are also able to access prescription medication listed on the provincial and territorial drug plans although some products are excluded from the IFHP (CIC, 2016a).

The coverage ends for any beneficiary who leaves Canada, becomes eligible under a provincial or territorial health insurance plan, or when a refugee claim made by an individual is withdrawn, abandoned by the IRB, or determined ineligible (CIC, 2016a). Government-assisted refugees, privately sponsored refugees, refugees sponsored by an organization approved by the IRCC, and certain individuals resettled on compassionate and/or humanitarian grounds are provided with basic, supplemental and prescription drug coverage (Olsen et al., 2014). Their basic coverage is only provided until they qualify for provincial/territorial health insurance (Olsen et al., 2014). Supplemental and prescription drug coverage is provided as long as they are receiving income support from "Resettlement Assistance Program" (RAP) or until the individual is not under a private sponsorship anymore (CIC, 2016a). The second group of beneficiaries, protected persons, are covered under basic, supplemental and prescription drug coverage (CIC, 2016a). This coverage "is provided for 90 days from the date the asylum claim is accepted, or until they become eligible for provincial/territorial health insurance" (CIC, 2016a).

Finally, refugee claimants, ineligible refugee claimants, rejected refugee claimants, and those receiving a stay or removal are provided with the same duration of basic, supplemental, and prescription drug coverage (CIC, 2016a). This means that until a beneficiary becomes eligible under a provincial or territorial health insurance policy, or if they leave Canada, they will receive their IFHP benefits (CIC, 2016a). However, an immediate cancellation will take place once an individual's asylum claim is withdrawn, abandoned, or presumed ineligible for a pre-removal risk assessment (PRRA) (CIC, 2016a). The overarching theme of the IFHP is to provide temporary and 
limited healthcare coverage of essentially the same services to different groups of migrants including refugees, refugee claimants, detainees under the IRPA, victims of human trafficking, and rejected refugee claimants.

Nonetheless, there are different periods of delays and administrative problems that can cause certain groups of eligible beneficiaries to remain at a disadvantaged position. For example, sometimes, there are asylum seekers that continue to reside in Canada without any access to their IFHP benefits due to processing delays (Gagnon, 2002). Hence, those seeking eligibility determination for their refugee claims are put in a position whereby no health coverage is provided due to administrative or processing delays (Gagnon, 2002). Nevertheless, the humanitarian approach undertaken by Canada to provide healthcare for those seeking protection is evident in the IFHP. Although different groups of migrants covered under the IFHP are subject to different limitations depending on their legal status, it is a progressive federal program that enables migrant populations to access healthcare services regardless of the limitations and/or barriers they face.

\section{Policy Analysis: Provincial and Municipal}

\section{Ontario Health Insurance Act}

The Ontario Health Insurance Act, Regulation 552, pertaining to the Ontario Health Insurance Plan (OHIP) outlines the eligibility criteria as well as the conditions for health coverage in Ontario (RRO 1990, Reg 552). In order to become an insured person, an applicant must obtain an eligible status. A few applicants that possess an eligible status include Canadian citizens, permanent residents (after a three-month waiting period), a person in need of protection or convention refugees, and temporary residents (RRO 1990, Reg 552). The Ontario government highly recommends that all publicly funded healthcare programs request eligible residents to present their health cards before accessing a healthcare service (Ontario Ministry of Health, 2009). 
If the ministry finds that a person is incapable of presenting their eligibility and health entitlements to the government, then their coverage may be cancelled (Ontario Ministry of Health, 2009). In addition, anyone suspected of accessing a healthcare service for which they are ineligible - such as an undocumented/non-status migrant - may face up to 10 years of imprisonment (Ontario Ministry of Health, 2009).

An ineligible person may have a child that is born in Canada and therefore, the child may be eligible for healthcare coverage. In this case, parents of the eligible child must prove that they have made Ontario their primary place of residence (Ontario Ministry of Health, 2011). The downfall to these eligibility criteria for children with ineligible parents is that those parents without documentation or a legal status may face deportation for presenting identification and a form of residence in Ontario (Goldring et al., 2009). Even if their child is born in Canada and they are eligible for Canadian citizenship, the non-status parents continue to remain underground in fear of deportation and exacerbate theirs and their children's' vulnerability (Goldring et al., 2009).

The eligibility criteria illustrated in OHIP almost provides hope for ineligible residents that their children's' lives are protected under the government's health insurance policy. Nonetheless, undocumented immigrants categorized with the rest of the ineligible residents are placed at a higher risk than any other precarious immigration status individual due to the fact that they are illegally residing in Canada (Magalhaes et al., 2010). Therefore, their children may be eligible under OHIP, yet the parents' invalid documentation can result in deportation, imprisonment, or another form of punishment if they are reported to the authorities (Goldring et al., 2009). This also means that uninsured and undocumented women with prenatal needs are less likely to access healthcare facilities during pregnancy, and after birth which can be damaging for them and their child (McKeown, 2013). This places them in a position that can create severe mental and physical 
problems as they are unsure about the limited options with which they are faced (McKeown, 2013).

Thus, the Ontario Health Insurance Act provides children with non-status parents an opportunity to access healthcare services, but the parents are placed in a disadvantaged position whereby their identification can be exposed. Resultantly, several campaign initiatives have promoted the rights and freedoms of non-status individuals claiming that immigration status should not be prioritized before an individual's human rights (McKeown, 2013).

\section{Don't Ask Don't Tell \& Access T.O}

Toronto is the first sanctuary city in Canada to implement a strategy that seeks to protect undocumented migrants from deportation when they access public services including healthcare (No One is Illegal-Toronto, 2004a). The Don't Ask Don't Tell policy ensures that a non-status resident accessing a city service such as a walk-in clinic will not be discriminated against on the basis of their immigration status (No One is Illegal-Toronto, 2004b). In addition, healthcare practitioners should not be able to inquire about a person's immigration status when they are in need of a service (No One is Illegal-Toronto, 2004b). In case a city worker discovers the immigration status of an ineligible resident, they should not report this information to Citizenship and Immigration Canada (No One is Illegal-Toronto, 2004b).

No One is Illegal-Toronto sought to create a formal policy that would be adopted by the city to ensure the safety of undocumented immigrants accessing city-funded services in Toronto. Thus, the implementation of DADT eventually led to the development of Access T.O, to which the City Council made a commitment (Access T.O, 2013). The City Council formally adopted this policy ensuring that all residents of Toronto have access to services without the fear of being asked for proof of immigration status (Access T.O, 2013). Furthermore, identification must be provided when a person chooses to access a service but this identification will be protected under the 
Municipal Freedom of Information and Protection of Privacy Act (MFIPPA) (Access T.O, 2013). In the healthcare department however, it is often at the discretion of service providers and community agencies to ask for identification.

To explain, a person needs to present proof of identification in order to clarify that they are a resident of Ontario. This can include a telephone or utility bill as long as it indicates that they are living in Toronto (Access T.O, 2013). However, the MFIPPA protects their privacy by ensuring that the city "cannot collect personal information unless it is legally authorized to do so by statute or by law" (Access T.O, 2013). It is at the City's discretion to aid law enforcement if a situation arises where an investigation is occurring pertaining to an undocumented migrant (Access T.O, 2013). If it is mandatory for the city to disclose information for an investigation, there must be a written request from the agency (Access T.O, 2013).

The DADT policy and Access T.O aim to promote equal rights for all residents of Toronto regardless of their immigration status. These strategies have led to the implementation of a municipal program where the city continues to review the current process of services provided and improve its program to serve undocumented Torontonians (Access T.O, 2013). A report pertaining to the progress of Access T.O Initiative on December 9 and 15,2015, revealed that the city council adopted an approach that would ensure accurate and helpful customer service for undocumented Torontonians (City of Toronto, 2015). Moreover, a report dated June 10, 2014, portrayed the adoption of another approach by the city council in which a request was made to the provincial and federal governments to review their immigration and refugee policies (City of Toronto, 2014). It requested the government to provide ramifications for their immigration policies and establish changes that can provide a better quality of life for uninsured residents (City of Toronto, 2014). These reports have done an excellent job in acquiring information from public facilities to 
understand the ongoing issues with providing services. They also enable members of the city council to develop future strategies in order to create better opportunities for undocumented Torontonians.

\section{Literature Review}

Authors' Main Arguments: Status and Access to Health Care

In the article written by Sandra Elgersma titled, "Immigration Status and Legal Entitlement to Insured Health Services", the author explains health care access for permanent residents, refugees, and asylum seekers/refugee claimants (2008). Elgersma clearly states that a permanent resident is a person whose right to come and live in Canada permanently has been granted (Elgersma, 2008). A permanent resident must wait three months in Ontario to obtain a health card and access health care services similar to Canadian citizens (Elgersma, 2008). Similarly, Campbell et al. state that permanent residents receive the same level of access to provincial healthcare programs as Canadian citizens and that refugees are entitled to the Interim Federal Health Program (IFHP) (Campbell et al., 2012). However, permanent residents must complete a three month wait period before obtaining full access to a provincial healthcare program (McKeown, 2013). This three-month gap is important to acknowledge as it can be detrimental to the livelihood of individuals that are in dire need of medical attention. One example of a difference in policy is that prescription medication covered under a provincial program such as the Ontario Health Insurance Plan (OHIP) is not covered under the IFHP (Campbell et al., 2012).

Although failed refugee claimants are eligible for IFHP benefits until their removal, they abandon their applications and hide underground fearing removal from Canada (Miklavcic, 2011). These refugee claimants may be denied 'protected person status' but they cannot be returned to their country of origin as they come from a country with "generalized insecurity" (Elgersma, 
2008). Thus, these refugee claimants remain in a precarious immigration status and are also provided with limited access to IFHP benefits (Elgersma, 2008). Miklavcic's article revolved around the barriers faced by undocumented immigrants due to the positions in which they are placed by the government. This article conveys the struggles faced by individuals that have hidden underground due to their non-status. Thus, these individuals are currently residing in Canada and are unable to access services that are crucial for a good quality of life (Miklavcic, 2011).

A report written by the Medical Officer of Health Ontario, David McKeown, indicates the problems associated with all medically uninsured individuals (2013). It contributes to the literature surrounding undocumented immigrants by conveying the importance of funding for specific healthcare programs and services targeting a very vulnerable population (McKeown, 2013). The report highlights the most important healthcare needs for uninsured individuals including gynecological care and medical attention directed towards non-status children (McKeown, 2013). The author argues that undocumented women are in dire need of gynecological care which is necessary in foreseeing any problems that women may face during their pregnancy (McKeown, 2013). The report further discusses non-status children that suffer from common and treatable illnesses which tend to worsen and become debilitating due to the barriers they face in accessing health care services (McKeown, 2013). Therefore, this report provides valuable information to the existing literature by indicating the medical attention that needs to be directed towards certain minority groups and the funding that can potentially aid in providing assistance (McKeown, 2013).

Once an individual loses their refugee status or fails to meet their visa requirements amongst several other factors, they fall under the category of 'precarious immigration status, 'undocumented immigrant' or 'illegal' (Miklavcic, 2011). Hence, Miklavcic took a different approach to understanding access to health care by non-status residents living in precarious 
conditions (2011). This article argues that the dynamics of citizenship and human rights must be critiqued and analyzed when discussing the subject matter. It took a theoretical approach to the topic by touching upon Foucault's theories of governmentality and bio-power (Miklavcic, 2011). A theoretical approach such as bio-power is a useful form of critique on the topic of undocumented immigrants that are medically uninsured and face barriers to accessing healthcare. This theoretical lens acknowledges the broader issues of citizenship that indefinitely impact a person's legal status and questions the rights and services to which an individual is entitled (Miklavcic, 2011).

Similarly, Goldring et al. argue that a rights-based approach to understanding the vulnerability of precarious immigrant status individuals is crucial (Goldring et al., 2009). This is an interesting article as it also analyzes this topic using a theoretical and conceptual framework whereby the population's precarious status further pushes them into the margins of society (Goldring et al., 2009). Although the article does not specifically focus on access to healthcare services for undocumented immigrants residing in Canada, its theoretical perspective portrays the barriers to all public services that the population faces due to their legal/illegal status (Goldring et al., 2009). The notion of citizenship and immigrant status remains an essential topic of discussion for several other articles whereby the authors emphasize the detrimental impact of non-status or precarious status on residents that are unable to seek assistance for their medical needs (Brabant et al., 2012b, Simich, Wu, \& Nerad, 2007, \& McKeown, 2013).

Brabant \& Raynault make the argument that stricter immigration policies force individuals with precarious immigration status into the black market that are rarely regulated such as the food industry, domestic work, etc. (2012a). This can cause a mental breakdown whereby isolation, stress and anxiety, violence, and constant fear of deportation can become a living reality (Brabant \& Raynault, 2012a). Additionally, if a person accesses healthcare services, the fear of deportation 
combined with detrimental physical and mental health conditions can cause them to act irrationally such as leaving before the end of a treatment, delaying consultations, or finding alternatives such as illegal and informal networks (Brabant \& Raynault, 2012a). One of the major points made in this article is that healthcare professionals and institutions often state that there is a financial burden on providing services to individuals with precarious immigration status (Brabant \& Raynault, 2012a). However, it is argued that they are still contributing agents to the economy by use of products, paying for rent, purchases and taxes, and often being exploited for their cheap labour (Brabant \& Raynault, 2012a).

The authors state that Canada takes advantage of individuals with precarious immigrations status by exploiting them for labour yet creating barriers to access the services to which they should be entitled (Goldring et al., 2009). Brabant \& Raynault also state that undocumented migrants participate in the Canadian labour market; however, their lack of an official status does not provide them with an opportunity to access healthcare services even if they are contributing to the economy (2012a). They argue that practitioners have a moral commitment to provide healthcare services to individuals whose jobs place them in a position in which they are susceptible to debilitating injuries which would possibly result in death if not treated (Brabant \& Raynault, 2012a).

Temporary foreign workers are a prime example in this case as they are contributing to the economy with their labour and yet, they are faced with barriers to accessing healthcare services in Canada (Brabant \& Raynault, 2012a). Furthermore, the desire to remain in Canada and perform well in their work prevents temporary foreign workers from seeking medical attention related to their labour as they fear a removal of their visa (Brabant \& Raynault, 2012a). Although the Canadian government requests employers to provide the workers with private health insurance until they are eligible under a provincial/territorial program, studies have indicated that they are 
often exploited by their employers (Goldring et al., 2009). Moreover, temporary foreign workers often want their families to eventually reside in Canada and establish a good quality of life in the country. Thus, they often remain silent about any work related injuries or exploitative behaviours of their employers in the hopes that they do not jeopardize their chances of remaining in Canada such as having their visa removed (Brabant \& Raynault, 2012b).

Anita Gagnon conveys the importance of understanding issues with Canada's health care system specifically associated with the federal government. In her article, "Commission on the Future of Health Care in Canada - Responsiveness of the Canadian Health Care System", she states that the intention for the establishment of the Canada Health Act was to equalize access to health care (Gagnon, 2002). However, the current application of such policies is causing issues for immigrant populations with precarious immigration status. More significantly, the author focuses on the IFHP and the problems associated with the application of health services towards vulnerable newcomers including refugees and asylum seekers (Gagnon, 2002). The significance of understanding the different terminologies between landed immigrants, permanent residents, refugees, and asylum seekers, is that these statuses determine the level of access and type of health care the individuals will receive (Gagnon, 2002).

The Canada Health Act is another significant instrument that mentions the term "universality" to imply that all residents of Canada are entitled to adequate health care (Elgersma, 2008). However, residents are defined as those who are lawfully living within the jurisdiction making Canada their home (Elgersma, 2008). Although Gagnon argues that refugees and asylum seekers are not reaping the benefits of an equal health care system due to the limitations and barriers in the IFHP, Elgersma argues that undocumented immigrants also deserve recognition and protection despite their non-status (2008). The Canada Health Act does not recognize non-status 
individuals and failed refugee claimants as residents of the country and thereby excludes them from accessing services to health care (Elgersma, 2008). It is mostly up to the provincial and municipal governments and local NGOs or community health services to provide the access and support for non-status and uninsured individuals (Elgersma, 2008).

Elgersma mentions that there is an issue with the practical application of providing services to permanent residents, refugees, asylum seekers, and non-status individuals as health centres and service providers do not necessarily have the funds, time, and staff to manage the burden (2008). Gagnon makes a similar argument that service providers may not have the incentive to provide the care and support to these populations as they are not regulated and are often left feeling burdened (2002). Thus, even if cities such as Toronto have centres in place to provide services to these populations, there is not a regulated municipal policy that manages the services provided to undocumented or non-status individuals (Elgersma, 2008). It is also usually at the discretion of staff including doctors and other health care practitioners to determine to which individual they should offer their services (Elgersma, 2008). In her article, Gagnon also indicates that administrative delays leave many refugee claimants in a state of limbo where they do not have health insurance (2002). In addition, they are not eligible for provincial health care or IFHP benefits and this can greatly impact their health as they are not legally entitled to any health care policy as their precarious immigration status continues to worsen (Elgersma, 2008).

Campbell et al. have also found issues in the practical application of services offered to precarious immigration status individuals (2012). Their study indicated that precarious immigration status groups such as permanent residents and refugee claimants were often able to access healthcare better than non-status migrants (Campbell et al., 2012). For example, refugee claimants had doctors available to serve them as they have access to benefits - although limited - 
through the IFHP (Campbell et al., 2012). However, undocumented immigrants did not have any legal entitlements to health care services and therefore, they would either be denied care or they would have to get a reference under another individual's name to get prescription medication (Campbell et al., 2012). Individuals of precarious immigration status such as refugee claimants, refugees, and non-status immigrants are not given the same level of access to health care. Thus, their legal status determines the services they will be provided and whether a health care practitioner will accept or refuse to provide their services (Campbell et al., 2012). These authors expose the contradiction with Canada's notion of universal healthcare and the current limitations on access based on an individual's precarious status.

\section{Conceptual Framework}

\section{Critical Theory}

The research problem pertaining to immigration status and level of access to health care may be portrayed as inevitably unjust and incapable of change or progress. However, constant research alongside existing literature offers a considerable amount of knowledge that can provide updated statistics and information. This source of knowledge is a powerful tool that can make a difference in large or small amounts within local or even national policies. The idea that there is always a connection between knowledge and change is a theoretical framework known as critical

theory (Hoffman, 1989). The critical theory paradigm argues that society is constantly changing and that social conditions do not remain immutable (Hoffman, 1989). In addition, researchers conducting studies within the critical theory paradigm view society from an objective standpoint whilst simultaneously placing themselves within that society (Hoffman, 1989). To explain, critical theorists argue that they are also a product of the society in which they reside and therefore, their 
studies are grounded in the belief that they must seek knowledge pertaining to the social conditioning of themselves and others' in their society (Hoffman 1989).

The most important component of critical theory is the notion that humanity is capable of various potentialities that are limited by society. Thus, it is important for researchers to understand the social conditioning of people as well as understand society itself in order to provide recommendations for potential change (Hoffman, 1989). Most often, the result can be profound such as transforming social order and politics of a society to create a life for people that acknowledges their health and wellbeing (Hoffman, 1989). Therefore, this research paper is written from the perspective of a critical theorist in order to add further knowledge to the already existing literature on precarious immigration status migrants and their access to Canada's healthcare system while also arguing that change is possible. The possibility of change allows for recommendations to be formulated with a view to improving the human rights of non-citizens.

Several authors such as Campbell et al. (2012), McKeown (2013), Simich et al. (2007), Goldring et al. (2009), Brabant \& Raynault (2012), Miklavcic (2011), \& Elgersma (2008) have conducted analyses and studies from a similar perspective and their research has played a critical role in identifying the limitations and barriers faced by precarious immigration status individuals. Their methodologies and their findings have provided academics as well as political institutions with different perspectives, viewpoints, statistical data, and overall knowledge pertaining to the topic of interest. Hence, it is important to note that the current critical theory paradigm is reinforced by such valuable knowledge in the field whereby each author conveys the importance of understanding the society in which immigration has become a prominent topic of discussion. Furthermore, the research articles reveal the authors' intentions to guide future academics and potential political leaders to create a positive change in policies and documents. These efforts can 
create a positive change on the current stringent immigration processes and further narrow the gap between access to healthcare and barriers faced by immigrants with a precarious status.

\section{Theoretical Framework}

\section{Bio-Power}

Foucault's theory of biopower is an essential proponent of this research paper as it aims to identify the problems with categorizing people in different immigration statuses. The recommendations provided by authors such as Simich et al. (2007) and Miklavcic (2012) discuss issues surrounding the mental health of precarious immigration status individuals. Simich et al argue that there is an important need for understanding the impact of a multi-tiered healthcare system in Canada whereby certain groups of people are neglected due to their status and therefore unable to maintain a good quality of life and healthy wellbeing (2007). The authors argue that providing funding for more community mental health programs after conducting further research in this matter can create opportunities for migrants of precarious status to obtain services for their mental wellbeing which can also positively impact their physical wellbeing (Simich et al., 2007).

Furthermore, the recommendations made in Miklavcic's article suggest that necessary steps must be taken in primarily understanding the depressing situations in which non-status immigrants reside (2011). In doing so, it is argued that society will be able to better understand the living conditions in which non-status migrants reside that create multiple barriers detrimental to their physical and mental health (Miklavcic, 2011). The author makes the argument that stringent immigration policies and restrictions placed upon migrants of precarious status can be altered once people acknowledge the realities and continuous struggles faced by undocumented immigrants (Miklavcic, 2011). Hence, the author describes the negative consequences of the nation state's resistance to human rights by exercising its power over migrant bodies such as limiting their 
opportunities to accessing healthcare which is a necessary service in the development of a healthy lifestyle.

The significance of biopower in the analysis of limitations faced by precarious immigrations status individuals within the healthcare system is that it reveals the oppression faced by this population. The oppressive nature of the tiered healthcare system reveals its detrimental impact on peoples' lives where the value of an individual's life is determined by their citizenship status (Miklavcic, 2011). The distinction between a permanent resident, a refugee, a refugee claimant/ asylum seeker, and an undocumented migrant plays a significant role in determining the type of access a person will receive to healthcare services (Magalhaes et al., 2010). Thus, Foucault's theory of biopower argues that this distinction enables the government or the nation state to control people's bodies and determine which groups of people should have a better quality of life (Genel, 2006).

Power is exercised when a nation-state has the ability to decide on the quality of one's life and whether a person's life is of value, and therefore, its non-value (Foucault, 1982). Foucault and Agamben studied power relations by understanding this definition to explain bio-politics and biopower whereby a government distinguishes the life of certain individuals (Foucault, 1982). For example, it is argued that the concept of human rights is inferior to the notion of power in which a person is no longer just a human being, but also a refugee, asylum seeker, or illegal/undocumented migrant. Thus, according to Foucault and Agamben, this categorization is a political act that gives tremendous power to the nation-state in determining the value of these individuals' rights and the quality of life they should be provided (Genel, 2006).

The theory of biopower examined by Foucault and Agamben plays a critical role in understanding the healthcare policies that are limited towards certain populations. The role of 
biopower enables governments to exclude certain groups of people by discriminating against the lives of one category over the lives of another. Hence, human dignity, existence, and bare life, is undervalued as the ability to exercise power over collective bodies is implemented. The political categorization of groups by the nation-state in order to determine the standard of living and the quality of life they are provided is a form of control that intentionally places people in a position that can be debilitating to their health. Miklavcic concludes her article by arguing the very same point stating that, "the control over biological life and the prevention of death...seems more important than the recognition of human dignity" (Miklavcic, 2011).

\section{Legal Status and Human Rights}

One of the arguments made by Magalhaes et al. pertains to the issue of citizenship status whereby an alternative to public health insurance coverage being private health insurance remains inaccessible due to their non-status (2010). Simich et al. further emphasize a similar point stating that a person's status is an obstacle to acquiring attention for their medical needs as their status overlooks their human dignity (2007). Therefore, several municipal campaigns supporting precarious immigration status individuals encourage health care practitioners to provide services without looking into their legal status (Miklavcic, 2011). Miklavcic states that failed refugee claimants are the largest category of non-status immigrants in Canada and they do not have access to IFHP due to the abandonment or withdrawal of their application (2011).

The author revealed that an undocumented patient had attempted to commit suicide due to unfortunate circumstances that the individual had faced based on their non-status. The patient had taken several steps to ensure that they would receive a Canadian citizenship but it became impossible to obtain which only exacerbated their vulnerability in society (Miklavcic, 2011). Thus, the article reveals that the government metaphorically forces people to take desperate acts and 
measures as they are left with little to no options for creating a healthy lifestyle for themselves (Miklavcic, 2011). Therefore, the patient's attempt to commit suicide is viewed from the perspective of the author as an attempt to escape the security regime that would rather push people to hide underground and risk their lives instead of providing the necessary care for them based on their human dignity (Miklavcic, 2011). Similarly, Gagnon and Elgersma make the argument that basic human rights and a person's human dignity often seem to come second to a person's legal status (2011).

As citizenship and legal status play a key role in determining the level of access an individual receives to healthcare, a person with a precarious immigration status may develop occupational injuries which they leave untreated until it becomes an emergency care matter (McKeown, 2013). Moreover, it impacts youth with precarious immigration status where their treatable conditions worsen overtime as they are unable to access healthcare services (McKeown, 2013). Miklavcic concludes with her article by stating that a person's quality of life, standard of living, and overall human dignity is not as significant to the Canadian immigration system as control and systemic order (2011). It is emphasized that a life with limited rights and constant anxiety over an individual's future due to the fear of deportation is not a life that a person can enjoy which puts a strain on their mental health (Miklavcic, 2011). Hence, it becomes a matter of power over an individual's body that manages the systemic control of a population to contain a status quo that overlooks the quality of life and individual human rights (Genel, 2006).

Canadians are provided access to health care services across the nation but groups of newcomers such as refugees, asylum seekers, permanent residents, and temporary residents, face barriers that can jeopardize their health (Gagnon, 2002). In addition, different types of refugees are given different levels of access such as Convention refugees, government-assisted refugees, 
privately-sponsored refugees, or refugee claimants (Gagnon, 2002). Thus, within each category, there lies different subgroups that are further limited with accessing services based on their status. Hence, it is argued that a person's human dignity and their right to a good standard of living is often overlooked by the mere fact that one's status is inferior to another's thus excluding them from belonging in society.

\section{IFHP Federal Court Decision: Human Rights and Sovereign Power}

The differences in the programs and policies determined by an individual's legal status must be further analyzed and studied to understand the significance of citizenship status and legality. More importantly, their legality and illegality should not be a key determinant for accessing health care as Canada is a signatory to multiple international treaties wherein health is written as a human right (Heymann et al., 2013). The international legal instruments that portray the significance of health as a right to all people include the Convention on the Rights of the Child, Article 25 of the Convention on the Rights of Persons with Disabilities, Article 5 of the International Convention on the Elimination of All Forms of Discrimination Against Women, Articles 39 and 43 stated in the International Convention on the Protection of the Rights of All Migrant Workers and Members of their Families, and Article 12 of The International Covenant on Economic, Social, and Cultural Rights (OHCHR, 2008). Each of these instruments recognize the right to health and continue to promote equal opportunities to accessing healthcare services for all individuals.

In regards to healthcare, section 7 of the Charter states that Canadians have "the right to life, liberty, and security of the person and the right not to be deprived thereof..." (Canadian Charter, 1982, s.7). Although the right to healthcare is not explicitly outlined in the Canadian Charter, section 7 should be read in accordance with the conceptions of community welfare and 
individual wellbeing (Jackman, 1988). For example, the applicants in the Federal Court decision pertaining to the Canadian Doctors for Refugee Care v. Canada, 2014 argued that their section 7 rights were violated. Immigrant groups including refugee claimants were unable to access the IFHP under which they were covered prior to the cuts in 2012 (CDRC v. Canada, 2014, s.531). Thus, the applicants argued that their right to life, liberty, and security was not acknowledged by the federal government as their individual wellbeing was being compromised (CDRC v. Canada, 2014, s.498).

The applicants stated that their section 7 rights were violated insofar that the federal government deliberately denied some individuals from receiving healthcare coverage that was previously accessible (CDRC v. Canada 2014 , s.552). The judge dismissed the claim that the applicants' right to life, liberty, and security was violated but nonetheless asserted that the government's decision was discriminatory and detrimental to the health of ineligible refugee claimants (CDRC v. Canada, 2014, s.741). The judge defended the individual human rights of the applicants by following the principles of the Canadian Charter of Rights and Freedoms. The argument of a 'right to health care' was missing in the judgement but still revealed a significantly positive outcome in which the judge argued that specific immigrant groups being denied IFHP coverage were treated unfairly and unjustly. Consequently, the judge concluded that the federal government violated some of the Charter rights mentioned by the applicants as the federal government was unjustifiably placing these groups in a position that was debilitating to their health (CDRC v. Canada, 2014, s.1082).

The current securitization discourse justifies the differential treatment of non-citizens and the denial of healthcare services to some of them. The power to deny healthcare services to certain populations is obvious in the Federal Court case as the rhetoric of securitization is presented. The 
Canadian government rationalized its decision to make the drastic cuts by claiming that it was necessary in order to protect its nation from 'bogus refugees' and 'illegal migrants' (CDRC v. Canada, 2014, s.1082). This justification is evident in the CDRC v. Canada (2014) case where the federal government stated that, "Canadians have been clear that they do not want illegal immigrants and bogus refugee claimants receiving gold-plated health care benefits that are better than those Canadian taxpayers receive" (CDRC v. Canada, 2014, s.56). They further elaborate that they have deliberately made the cuts to the IFHP to protect Canada from such bogus claimants that should respect Canada's laws and leave the country after Canada's 'generous' system rejects them (CDRC v. Canada, 2014, s.56).

The process of securitization separates certain groups of people from the rest of society as they are perceived to be threats to the nation and therefore treated with suspicion because they cannot be trusted (Amin-Khan, 2015). The decision to deny treatment to migrants in dire need of healthcare services illuminates the impact of security politics that exclude and criminalize refugees by using terms as 'que-jumpers' and 'bogus' (Amin-Khan, 2015). The federal government created a sense of fear amongst its Canadian population by creating an image of refugees eliciting fear, anxiety, and insecurity (Amin-Khan, 2015). Furthermore, it sought to justify its actions by instilling a false sense of insecurity in the nation implying that refugee claimants were costing Canadian taxpayers millions of dollars, and that they were abusing Canada's 'generous welfare system' (Harris \& Zuberi, 2014).

These statements made by the federal government convey the rhetoric of securitization that has played a critical role in the stringent immigration policies under the name of national security (Amin-Khan, 2015). For example, the use of such terms as "bogus" or "gold-plated health care" gives a false sense of fear to the Canadian public that migrants are taking advantage of Canada's 
excessively fair and equal healthcare system (CDRC v. Canada, 2014, s.56). It gives way to assumptions that migrants are criminals and that Canada's universal health care system is attracting such groups thereby forcing the government to make the necessary cuts in deterring such crimes from taking place (CDRC v. Canada, 2014, s.55).

The use of a securitization discourse allows for changes that impact a large number of people by justifying that these changes are made in the name of national security (Amin-Khan, 2015). Thus, the exercise of sovereign power over immigration policies and migrant populations was prioritized in the IFHP cuts over individual human rights to deter 'bogus' refugees from remaining in Canada. Nevertheless, the judge's analysis revealed that the federal government was treating a poor, disadvantaged, and vulnerable population in an unjust manner (CDRC v. Canada, 2014, s.590). The judge asserted that certain human rights including the right to life, and at least minimal access to healthcare that can prevent life-threatening conditions from worsening should not be dependent on an individual's status or country of origin (CDRC v. Canada, 2014, s.1081).

Therefore, the decision to overrule the IFHP cuts highlights that human rights violations were evident by the federal government and that an already marginalized population should not be faced with exacerbated barriers to healthcare (CDRC v. Canada, 2014, s.1048). The federal government conceded that the changes made to the IFHP were based on perceptions and false beliefs about migrants instead of real evidence to indicate that the refugees were in fact taking advantage of Canada's healthcare program (CDRC v. Canada, 2014, s.1021). This is a landmark decision that outlines the importance of a human rights framework which plays a critical role in establishing judicial decisions. The Charter has been a significant legal instrument in guiding Supreme Court cases such as CDRC v. Canada, 2014. It provides a human rights framework to ensure that the federal government does not infringe upon an individual's basic human rights. 
Though the exercise of Canada's sovereignty on its nation may continue to promote security politics and increase stringent immigration policies, it is essential to acknowledge the profound impact of the Charter which can be used as a powerful tool in creating change.

\section{IFHP Federal Court Decision: Why were the 2012 Cuts Overruled?}

The IFHP was established for humanitarian reasons to provide eligible non-citizens with essential preventative and emergency medical services (Canadian Healthcare Association, 2012). In 2012, certain migrant populations including rejected refugee claimants that were once eligible under the IFHP were faced with drastic cuts that made them ineligible for benefits once received under the program (Canadian Doctors for Refugee Care v. Canada, 2014). Refugee claimants were also denied funding for certain medications available under supplemental coverage if they were seeking protection from a "Designated Country of Origin" (DCO) such as Mexico (CDRCv. Canada, 2014, s.3). A DCO is a country that does not produce refugees and often respects its human rights obligations to provide protection (Olsen et al., 2014). Thus, the federal government's 2012 cuts intended to process claims faster by rejecting claimants entering Canada from DCOs on the grounds that these countries had the ability to provide protection and did not produce refugees (Olsen et al., 2014). The Ministry of Citizenship and Immigration argued that individuals from DCOs were entering Canada on bogus claims to abuse the generous refugee system. Thus, they were deemed as capable instead of vulnerable people who had the means to enter Canada and therefore presented a false claim to take advantage of Canada's universal healthcare system (Olsen et al., 2014).

The discourse of securitization inevitably plays a role in this case as the federal government justifies the cuts by portraying the 'bogus refugee' as a threat to the nation state (Olsen et al., 2014). The government sought to separate genuine refugee claims from false refugee claims to 
justify the exclusionary practices such as denying healthcare to migrants in dire need of medical attention (Olsen et al., 2014). Although the case presents several complex themes and arguments, there is an important topic of discussion relevant to status and healthcare. Mainly, the IFHP cuts led to the expansion of an already existing gap pertaining to healthcare services for eligible beneficiaries. Consequently, the analysis of the decision reveals that protection provided to individuals remains to be determined by their immigration status which is inevitably an act of power.

The IFHP cuts in 2012 presented three tiers of healthcare coverage in ascending order from Public Health or Public Safety Health Care Coverage (PHPS), Health Care Coverage (HCC), to Expanded Health Care Coverage (EHCC) (CDRC v. Canada, 2014, s.61). Under this policy reform, a refugee claimant from a DCO would receive limited access to PHPS coverage only moving up to HCC once their claim was accepted (CDRC v. Canada, 2014, s.64). On the other hand, a refugee claimant from a non-DCO would receive HCC coverage while their claim was pending, and if rejected, it would move to the bottom of the tiered system which was PHPS coverage (CDRC v. Canada, 2014, s.73). In contrast, only government-assisted and privatelysponsored refugees would be given access to the EHCC, although it is to be noted that the coverage is similar, if not less than, to provincial and territorial insurance for low-income Canadian families (CDRC v. Canada, 2014, s.68). There is also a fourth class of refugee claimants who would be completely removed from coverage under the IFHP. This class is the PRRA-only claimants and they would not receive health insurance even if they were posing a risk to public health and safety (CDRC v. Canada, 2014, s.79).

There were several arguments pertaining to the IFHP cuts which indicated that the federal government had been discriminatory and unjust. One reason for overturning the decision 
highlighted in the judgement was determined by the health condition of an applicant named Hanif Ayubi (CDRC v. Canada, 2014, s.22). Mr. Ayubi was a failed refugee claimant who could not return to his country of origin since the Canadian government does not deem it safe for anyone to be deported to Afghanistan (CDRC v. Canada, 2014, s.22). In addition, his rejected refugee claimant status prevented him from accessing medications covered under the IFHP which was detrimental to his health as he had diabetes (CDRC v. Canada, 2014, s.23). Although the Minister granted the applicant with discretionary IFHP coverage that paid for his visits to the doctor, it did not cover the costs of insulin and other medications necessary for his health conditions that were once covered under the IFHP (CDRC v. Canada, 2014, s.24). In the meantime, Mr. Ayubi was able to access free samples by a CHC that was keeping him alive until the cuts were overturned (CDRC v. Canada, 2014, s.24).

The court found that there had been multiple complaints by people other than Mr. Ayubi who also had similar concerns pertaining to the IFHP cuts and their debilitating health conditions (CDRC v. Canada, 2014, s.171). Furthermore, Community Health Centres (CHCs) and health practitioners across Canada also reported that their clients once covered under the IFHP were facing problems similar to Mr. Ayubi (CDRC v. Canada, 2014, s.172). Thus, the denial of medications necessary for the lives of rejected refugee claimants such as Mr. Ayubi portrays the cruelty of the 2012 changes (CDRC v. Canada, 2014, s.682). The judge argued that it was demeaning for the federal government to place this group of migrants in a position that makes them practically beg for life-saving treatments (CDRC v. Canada, 2014, s.688). Hence, the judge concluded that Charter rights had been violated by stating that, "it sends the message that some lives are worth less than the lives of others. It is cruel and unusual treatment..." (CDRC v. Canada, 
2014, s.688). Thus, the ruling overturned the IFHP cuts and brought back the basic coverage that was accessible by all eligible beneficiaries including Mr. Ayubi.

Another significant reason for the court's decision to overrule the federal cuts pertained to children of ineligible parents. The Respondents argued that Canada is not obligated to follow the principles of the Convention on the Rights of the Child by providing equal rights to all citizen and non-citizen children (CDRC v. Canada, 2014, s.469). However, the judge argued that although the Canadian government has a right to exercise its sovereignty over migrant populations, children are often dependent on their parents' decisions and do not have a choice of where to migrate (CDRC v. Canada, 2014, s.638). Thus, the objective of the cuts to deter ineligible adults from freely accessing Canada's healthcare system also had a profound impact on the lives of their children (CDRC v. Canada, 2014, s.639). For example, the judge stated that, "denying health care insurance coverage to innocent children as a means of affecting the behaviours of their parents and others is illogical and unjust. It constitutes cruel and unusual treatment" (CDRC v. Canada, 2014, s.669). In other words, a parent's decision to migrate (whether legally or illegally) should not determine the denial of healthcare services to their children.

This is an important human rights argument as it indicates that the right of the child should be prioritized even if their parents are not eligible under the IFHP. The judge stated, "be that as it may, it is surely antithetical to the values of our Canadian society to visit the sins of parents on their innocent children" (CDRC v. Canada, 2014, s.664). The constant use of the terms 'innocent' as a form of victimizing children due to their parents' choices indicates that the parents are most often the 'enemy of the state' and therefore, their children should not be placed in the same category as them. The claim that the children are innocent and the parents have acted sinfully (i.e. entering Canada illegally) conveys that there are hierarchies even within the human rights 
framework. For example, it is implied that the parents have a lower chance of obtaining human rights similar to that of their children simply due to the fact that the parents had a choice in determining their immigration status by migrating to Canada and that their children did not. Nevertheless, this decision played an important role in establishing a discourse of human rights and immigration status. The discourse of human rights was portrayed throughout the federal court decision by illustrating the problems associated with denying healthcare to a vulnerable and disadvantaged population. Although the judge understood that the federal government had the right to exercise its power over migrant populations based on their immigration status, the judge rejected the federal cuts insofar that the immigration status of parents would also affect the livelihood of their children.

\section{IFHP Federal Court Decision: What Would Foucault Say?}

Several important points must be presented in this argument to explain the Honourable Madam Justice Mactavish's decision for repealing the reform. First and foremost, the judge overruled the federal government's IFHP cuts arguing that a refugee claimant arriving from a DCO should not receive lesser healthcare coverage than a refugee claimant seeking protection from a non-DCO (CDRC v. Canada, 2014, s.795). The judge conceded that the distinction made between refugee claimants from DCO and non-DCO countries was based on stereotypical assumptions that a non-DCO refugee somehow suffered more than a refugee from a DCO (CDRC v. Canada, 2014, s.871). Moreover, the applicants argued that the IFHP cuts should be repealed, and that resettled refugees and asylum seekers should be provided with similar coverage to that of permanent residents; equating to coverage which Canadian citizens receive (CDRC v. Canada, 2014, s.452). However, the judge stated that it would not be any fairer to Canadians if the government started to provide coverage that is comparable to that of working Canadians (CDRC v. Canada, 2014, s.621). 
Nor would it be any fairer to Canadians that PRRA-only refugee claimants do not receive health insurance because it would put the lives of Canadians at risk (CDRC v. Canada, 2014, s.622).

Thus, these are important points to consider. Although the cuts were overruled, one of the reasons was based on the idea that there should not be a distinction made between DCO and nonDCO refugee claimants. In addition, the judge acknowledged that the PRRA-only applicants were placed in a very vulnerable and unsafe situation. Nevertheless, the wording of the decision provides a form of interpretation that can lead a reader to argue that the judgement was benefiting Canadian citizens insofar as much that health conditions threatening the safety of the public could now be diagnosed (CDRC v. Canada, 2014, s.1052). For example, it is stated, "nor is it somehow fairer to Canadians that those... receive[ing] no health insurance... puts the health and safety of those same Canadians at risk" (CDRC v. Canada, 2014, s.950). In addition, the judge did not find it unfair or unjust that a person's determination of eligibility was based upon their immigration status (CDRC v. Canada, 2014, s.1083).

These decisions imply that the prioritization of Canadian citizens over any other resident in Canada is greatly considered. It can be argued that the judge made an impartial and fair decision to revoke the IFHP-cuts and gave eligible beneficiaries a chance of receiving some form of health care coverage that would have been otherwise denied. Nevertheless, it is crucial to debunk the arguments made by the judge and analyze the reasoning to understand the value of immigration status. In this case, the decision was based on removing the unfair distinction between DCO and non-DCO countries, and giving access to coverage for PRRA-only applicants who may suffer from health conditions that could jeopardize the lives of Canadian citizens.

It is evident that the life of PRRA-only applicants was less valued than the life of Canadians who may be exposed to their life-threatening health conditions. As Foucault would argue, "it is 
the power to 'make' live and 'let' die" (Genel, 2006). This is the power provided to a sovereign that can determine the value of bodies that are deserving of protection, and those that are not (Genel, 2006). A rejected refugee claimant's immigration status greatly limits their ability to contribute to their and their families' wellbeing as the sovereign state has determined that their life is not of any value (Genel, 2006). A judicial system repealed the changes that would have further exacerbated the vulnerability of this population, and yet, their vulnerability does not seem to be reduced. This analysis partially reveals that a PRRA-only applicant may have been granted healthcare coverage under the IFHP for reasons including the public safety of Canadians, instead of reasons based on human dignity and the acknowledgement of their being human (Genel, 2006).

\section{DADT and Access T.O: Practical Application}

\section{Community Health Centres}

The DADT and Access T.O policies campaign for the rights of all Torontonians with specific attention geared towards the uninsured and undocumented populations that are placed in vulnerable positions. However, there are several limitations and barriers in the application of these policies. For example, Isabel Perez-Doherty wrote an audit report for the FCJ Refugee Centre in Toronto to illustrate the current problems faced by undocumented immigrants and service providers (Perez-Doherty, 2015). Its objective was to identify the areas of improvement to the City of Toronto regarding the implementation of services including healthcare under the Access T.O initiative (Perez-Doherty, 2015). There were a total of 87 audits of which 17 related to the healthcare practices. The audit report found that undocumented immigrants were struggling most with accessing dental health services, getting flu shots, CPR or first aid, and when trying to see a doctor (Perez-Doherty, 2015). In addition, the report revealed that two out of the 17 agencies in Toronto did not accept any individual without proof of identification or documentation (Perez- 
Doherty, 2015). Eight centres provided the auditors with the correct information regarding their approach to providing services to undocumented immigrants (Perez-Doherty, 2015). The remaining health centres failed to provide accurate information or they reported that they were unaware about the steps to be taken if an undocumented immigrant needed medical attention (Perez-Doherty, 2015).

This report reveals that it is still up to the discretion of healthcare practitioners to decide whether they want to accept a patient who does not have documentation. Furthermore, it portrays the current policies that are not regulated in order to ensure the correct implementation of its principles. Access T.O is a formal policy that should be regulated by the municipality of Toronto to emphasize the importance of its initiative. Nevertheless, there are clinics situated throughout Toronto that acknowledge the ongoing barriers and limitations faced by uninsured individuals due to the unfair provision of services provided by healthcare practitioners. For example, the FCJ refugee centre operates a small clinic for precarious status immigrants including non-status individuals (FCJ Refugee Centre, 2012). This clinic values the lives of uninsured residents and undocumented immigrants by providing them with medical assistance that would be otherwise impossible to obtain (FCJ Refugee Centre, 2012).

Similarly, the West End Non-Insured Walk-in Clinic (NIWIC) is partnered by seven Toronto-based Community health centres promoting equal health opportunities for precarious status immigrants (NIWIC Annual Report, 2015). It also provides services to permanent residents during their three-month wait period as they are also uninsured clients unable to obtain a health card (NIWIC Annual Report, 2015). The clinic hopes to mitigate these financial burdens on their uninsured clients by partnering up with other $\mathrm{CHC}$ s that can provide preventative services before an individual requires emergency medical attention (NIWIC Annual Report, 2015). Nonetheless, 
CHCs including NIWIC face limited funds that can impact the level of services they can provide to their clients and the number of resources that are made available (NIWIC Annual Report, 2015).

Currently, there are 22 active CHCs in Toronto from a total of 74 CHCs in Ontario that are providing medical services to undocumented immigrants; however, funding is greatly limited (Association of Ontario Health Centres, 2016). Currently, they are funded by the Ontario Ministry of Health and Long-Term Care and other donor agencies that are interested in providing healthcare services to vulnerable and disadvantaged populations (Surani, 2013). Yet, not all non-status residents are able to get the care that they need due to "capacity limitations and criteria for accepting new patients" (Sidhu, 2013). The funds allocated to these CHCs are limited based on numerous reasons including budgeting, resources, location of the $\mathrm{CHC}$, etc. (McKeown, 2013). Thus, it is argued that the current funding for these clinics is insufficient and it continues to place a burden on practitioners seeking to provide adequate healthcare for undocumented immigrants (Magalhaes et al., 2010). Moreover, insufficient funding often results in delayed care for uninsured residents as $\mathrm{CHCs}$ are unable to treat patients with their limited resources (Magalhaes et al., 2010). Consequently, delayed care can lead to debilitating health conditions, poor follow-up, poor mental and physical health amongst non-status immigrants, and increased morbidity (Magalhaes et al., 2010).

The barriers faced by CHCs, community agencies, and nongovernmental organizations far exceed insufficient funding. For example, precarious immigration status individuals without health insurance have to wait for a lengthy period of time in order to access programs and services (Sidhu, 2013). There is also a fear by staff working in the agencies that providing services to non-status patients will place a burden on their workload, and put pressure on the already limited existing agency resources (Sidhu, 2013). Front-line staff also reported unawareness of their own legal rights 
if they were to be approached by law enforcement or immigration officials (Sidhu, 2013). Most often however, the wait times play a crucial role in the administration of services for non-status residents of Toronto (Sidhu, 2013). The wait times range from a week to half a year (Sidhu, 2013). Most often, agencies understand that immigration status should not be a criterion for providing healthcare services but nonetheless, they are faced with limited funds and a lack of resources (Sidhu, 2013). Thus, the agencies are often forced to impose delays and wait times on their patients and thereby having a profound impact on the wellbeing of uninsured residents (Sidhu, 2013). Additionally, undocumented immigrants also fear accessing healthcare services as it will be discussed below.

\section{Non-Compliance of TPS and its Implications on Undocumented Immigrants}

A recent report by No One Is Illegal-Toronto conveyed the ongoing discrimination and biases present in the policing services of Toronto. Currently, the Toronto Police Services (TPS) is still largely inaccessible by undocumented immigrants residing in Toronto as they fear being reported to the Canada Border Services Agency (CBSA) (No One Is Illegal-Toronto, 2015). This report revealed that, "the TPS is the most frequent user of the CBSA Warrant Response System" (No One Is Illegal-Toronto, 2015). This system is managed by the CBSA call centre which is available 24/7 claiming that it seeks to ensure the effectiveness of all removal orders (No One Is Illegal-Toronto, 2015). The report found that $83 \%$ of the calls made by TPS to this system were to actively seek out information regarding the undocumented immigrants residing in Toronto (No One Is Illegal-Toronto, 2015). To explain, the most common reason for calling the CBSA was "to inquire about the immigration status on an individual even when no immigration warrant appears on the CPIC [Canadian Police Information Centre]" (No One Is Illegal-Toronto, 2015). This practice depicts the active efforts taken by the TPS in inquiring about individuals that they deem 
suspicious of an undocumented status (No One Is Illegal-Toronto, 2015). Thus, this raises questions surrounding the intentions of the TPS and whether undocumented immigrants can feel safe in reporting crimes and concerns to a service that seeks to protect its community.

The implications of the non-compliance to the DADT policy is evident in the report whereby undocumented immigrants do not feel safe when encountering TPS as they fear they will be reported to the federal authorities (McKeown, 2013). Undocumented immigrants that have witnessed a crime for which the TPS requires a testimony are often arrested by the officers and detained by CBSA for further processing (No One Is Illegal-Toronto, 2015). For example, one witness to a crime stated that they were detained in an Immigration Holding Centre for two and a half months once their immigration status was disclosed to the police officers (No One Is IllegalToronto, 2015). The report also highlighted the barriers of accessing TPS by undocumented immigrants that are victims of domestic violence. In this case, a woman agreed to report her perpetrator but she was unfortunately inspected by the police and handed over to federal authorities (No One Is Illegal-Toronto, 2015).

In another case, a service provider reported that the TPS subjected one of their clients to an immigration status check which eventually resulted in deportation for that individual (No One Is Illegal-Toronto, 2015). This example is significant in indicating that the involvement of TPS in other accessible services can create fear amongst undocumented immigrants from accessing these services, including healthcare. Assumptively, shelters and/or mental health clinics may propose to a client that they should report their concerns to the TPS for any number of reasons just as the woman chose to report her perpetrator on the insistence of the shelter (No One Is Illegal-Toronto, 2015). In doing so, undocumented immigrants would choose to remain silent and avoid any encounters with the TPS in fear of detainment and potential deportation by the CBSA. 
Interestingly enough, the TPS does not have a legal obligation to report an individual's legal status once it has been disclosed (No One Is Illegal-Toronto, 2015). Instead, the TPS possesses the power to choose between telling the federal authorities about an undocumented immigrant or remaining silent about the immigration status altogether (No One Is Illegal-Toronto, 2015). This power enables the TPS to actively seek out and often report undocumented immigrants to CBSA (No One Is Illegal-Toronto, 2015). Thus, No One is Illegal-Toronto argues that the practical application of the DADT policy is evidently absent in the TPS and therefore, it should be removed from the list of accessible services for undocumented immigrants (No One Is IllegalToronto, 2015). Thereafter, the City should take appropriate measures in developing a strategy that requires the TPS to comply with the DADT policy (No One Is Illegal-Toronto, 2015). Not only will undocumented Torontonians place their trust in TPS, they will feel more comfortable in accessing other services such as healthcare or housing without fearing that a police officer may be pursuing them in these areas (No One Is Illegal-Toronto, 2015).

\section{Conclusion: Next Steps}

The mental and physical health concerns of precarious immigration status individuals including refugee claimants and undocumented migrants are overwhelming (McKeown, 2013). Immigrants with a precarious status are usually placed in situations where access to services such as health, housing, and/or employment, prevents them from enjoying a decent standard of living (McKeown, 2013). They experience long-term stress, stigma based on their status, and ongoing fear of deportation and detention (McKeown, 2013). Additionally, they are exploited for their wage labour as employers are aware of their precarious immigration status and thus, their desperation for an income (McKeown, 2013). Consequently, they are employed in occupations where safety is not considered and occupational hazards become prominent (McKeown, 2013). 
Hence, not only do individuals face limitations with accessing healthcare if an occupational injury persists, they also face barriers to more crucial, and mandatory services that can provide a better quality of life. For these reasons, it is evident that an individual's immigration status is a key determinant in the type of services that they will be provided and the opportunities that they will have to pursue a healthy lifestyle.

Foucault's theory of biopower indicates that the body is an object of power that is legally and politically bound to the mechanisms of sovereignty (Genel, 2006). The body is perceived as an object of discipline by a sovereign nation that determines the worth of individuals through their hierarchical existence which becomes dependent on the institutions of society (Lilja \& Vinthagen, 2014). In addition, Foucault's theory of biopower indicates that the exercise of power is not only suppressive, but it is also productive in that it categorizes individual identities with each having its own place in society (Lilja \& Vinthagen, 2014). Thus, biopower is the governance of life and society which is evident in the current rhetoric of securitization. The federal government justified its actions for denying healthcare coverage to certain groups of immigrants by stating that they were deterring criminal migrants who were taking advantage of Canada's universal healthcare system (CDRC v. Canada, 2014, s.56). The securitization discourse creates a sense of fear amongst the population that migrants such as 'bogus refugees' are criminals and Canada is a humanitarian nation that should strengthen its policies to protect itself from these foreign bodies (CDRC $v$. Canada, 2014, s.56).

In this case, the sovereign nation has established a hierarchy wherein migrant bodies are not valued on the same level as Canadian citizens (Genel, 2006). The securitization discourse enables the federal government to justify its actions for denying healthcare coverage to groups of migrants that they deem unworthy of such access. In doing so, the government creates a 
hierarchical institution of healthcare in which a person's status determines the level of access they will receive. Those whose lives are deemed less valuable and less worthy will be placed at the bottom of the hierarchy which further exacerbates their vulnerability not just in their health, but in their socioeconomic status, political status, and social status overall. Thus, biopower is concerned with controlling the body of a population which is intertwined with the control over their health, productivity, behaviours, and overall placement in society (Lilja \& Vinthagen, 2014).

The discourse surrounding the impact of an individual's precarious immigration status and their ability to access healthcare services portrays the importance of campaigning and human rights movements that can make a difference. The DADT and Access T.O policies are a prime example of such campaigns that began with a discussion on immigration status and its profound impact on their quality of life. Therefore, ongoing research and studies pertaining to the policies impacting precarious immigration status individuals can expose the gaps and barriers that must be closed. It is important to spread awareness by combining the literature that has thus been gathered which can further promote a change in policies.

In addition, it is equally essential to spread awareness regarding power relations and the discourse of securitization. There have been claims made against immigrants with a precarious status arguing that these people are 'bogus' and 'illegal' (Amin-Khan, 2015). This claim was evident in the changes made to the IFHP in which the Canadian government argued that refugees were going to take advantage of Canada's universal healthcare system (CDRC v. Canada, 2014). For example, the cuts made to the IFHP in 2012 exposed the government's attitude in providing healthcare to individuals whose immigration status determined the value of their life. The changes aimed to separate 'bogus' asylum seekers from 'genuine' claimants which created a dichotomy that divided classes of immigrants. 
The social construction of immigrant statuses is part of a larger international context wherein power relations play a significant role in forcing groups of people to flee their homes (Amin-Khan, 2015). Therefore, it is crucial for society to understand that the barriers faced by individuals with a precarious immigration status are a result of global power relations and the rhetoric of securitization (Amin-Khan, 2015). In addition, the ongoing campaigning strategies in the municipality of Toronto and the commitment made by the City Council in providing uninsured residents and non-status immigrants with opportunities to access public services conveys the necessary steps that can eventually result in policy changes. For instance, the progress reports encourage members of the City Council and society as a whole to continue upgrading and improving their services. The reports also encourage the provincial and the federal governments to rethink their strategies and provide alternative solutions to the current policies embedded with the discourse of securitization.

Currently, a person's immigration status determines the type and level of access they will be provided to healthcare services in Canada. Their lives as human beings are placed second to their lives as either refugees, asylum seekers, undocumented/non-status migrants, or temporary workers. One individual may receive a free healthcare service while another must pay a bill for the same service based on the mere fact that one was a citizen and the other was a precarious status immigrant. However, the critical theory paradigm supports the initiatives of campaign groups and social activism that enables society to produce positive results. The continuous support provided by the community health centres in Toronto and the ongoing reports based on audits and research conducted by non-profit organizations allow for the municipality of Toronto to review its progress. These initiatives are powerful tools in creating change as they enable supporters and activists to combine their efforts and push for solutions at a local, provincial, and even the federal levels of 
government. Additionally, ongoing academic research is equally necessary as it provides future researchers, activists, teachers, students, and society at large, the knowledge to contribute to future societal and political changes. Eventually, it could lead to a governing nation that promotes humanitarian immigration policies where an individual's human dignity is prioritized over their immigration status. 


\section{Bibliography}

Access Alliance: Multicultural Health and Community Services. The West End Non-Insured Walk-In Clinic (NIWIC) Annual Report: April 2014-March 2015. Retrieved from http://accessalliance.ca/programs-services/primary-health-care/walk-in-clinic/

Access T.O. (2013). Access T.O for Undocumented Torontonians. Retrieved from City of Toronto website under Social Development:

http://www1.toronto.ca/wps/portal/contentonly?vgnextoid=9dfc33501 bac7410V gnVCM100000 71d60f89RCRD

Amin-Khan, T. (2015). Security and Its Impact on Migrants and Refugees. In Bauder, H. \& Shields, J. (Eds.). Immigrant Experiences in North America: Understanding Settlement and Integration. ON: Canadian Scholars' Press.

Association of Ontario Health Centres. (2016). CHC Fact Sheet. Retrived from the Association of Ontario Health Centres website under Community Health Centres: https://www.aohc.org/chcfact-sheet

Brabant, Z. \& Raynault, M. (2012a). Health Situation of Migrants with Precarious Status: Review of the Literature and Implications for the Canadian Context-Part A. Social Work in Public Health, 27(4), 330-344

Brabant, Z. \& Raynault, M. (2012b). Health of Migrants with Precarious Status: Results of an Exploratory Study in Montreal—Part B. Social Work in Public Health, 27(5), 469-481

Campbell, R. M., Klei, A. G., Hodges, B. D., Fisman, D., \& Kitto, S. (2012). A Comparison of Health Access between Permanent Residents, Undocumented Immigrants and Refugee Claimants in Toronto, Canada. Journal of Immigrant Minority Health, 16(1), 165-176

Canada Health Act, Revised Statutes of Canada (1985, c. C-6). Retrieved from the Department of Justice Canada website: http://laws-lois.justice.gc.ca/eng/acts/c-6/fulltext.html

Canadian Charter of Rights and Freedoms. (1982). Constitution Act, 1867 to 1982. Retrieved from the Justice Laws Website under Constitutional Documents: http://lawslois.justice.gc.ca/eng/const/page-15.html

Canadian Doctors for Refugee Care v. Canada (Attorney General), 2014 FC 651. Retrieved from the Federal Court website under Federal Court Decisions: http://decisions.fct-cf.gc.ca/fccf/decisions/en/item/72437/index.do

Canadian Healthcare Association. (2012). Changes to the Interim Federal Health Program: Position Statement. Retrieved from the HealthCareCAN website under Policy Positions: http://www.healthcarecan.ca/supporting-service-excellence/policy-positions-2/ 
Citizenship and Immigration Canada (CIC). (2016a). Interim Federal Health Program Policy. Retrieved from the Department of Immigration, Refugees, and Citizenship Canada website: http://www.cic.gc.ca/english/department/laws-policy/ifhp.asp

Citizenship and Immigration Canada (CIC). (2016b). Guide 5568: Application for Interim Federal Health Program Coverage. Retrieved from Citizenship and Immigration Canada website under Applications forms and guidelines: http://www.cic.gc.ca/english/information/applications/guides/5568ETOC.asp

City of Toronto. (2014). Access to City Services for Undocumented Torontonians: City Council Decision. (Report no. CD29.11). Retrieved from http://app.toronto.ca/tmmis/viewAgendaItemHistory.do?item=2014.CD29.11

City of Toronto. (2015). Access to City Services for Undocumented Torontonians: Progress of the Access T.O Initiative. (Report no. CD8.4). Retrieved from http://app.toronto.ca/tmmis/viewAgendaItemHistory.do?item=2015.CD8.4

Committee on Economic, Social, and Cultural Rights, General Comment No. 20. NonDiscrimination in Economic, Social and Cultural Rights. (2009). Retrieved from the World Health Organization website: http://www.who.int/mediacentre/factsheets/fs323/en/

Elgersma, S. (2008). Immigration Status and Legal Entitlement to Insured Health Services. Library of Parliament: Political and Social Affairs Division.

FCJ Refugee Centre. (2012). Primary Health Care Clinic. Retrieved from the FCJ Refugee Centre website under Settlement Programs: http://www.fcjrefugeecentre.org/ourprograms/settlement-programs/

Foucault, M. (1982). The subject and Power. Critical Inquiry, 8(4), 777-795

Gagnon, A. (2002). Commission on the Future of Health Care in Canada: Responsiveness of the Canadian Health Care System Towards Newcomers. Retrieved from the Government of Canada website under Government of Canada Publications: http://publications.gc.ca/collections/Collection/CP32-79-40-2002E.pdf

Genel, K. (2006). The Question of Biopower: Foucault and Agamben. Rethinking Marxism, 18(1), 43-62

Goldring, L., Berinstein, C., \& Bernhard, J. K. (2009). Institutionalizing Precarious Migratory Status in Canada. Citizenship Studies, 13(3), 239-265

Harris, H.P \& Zuberi, D. (2014). Harming Refugee and Canadian Health: The Negative Consequences of Recent Reforms to Canada's Interim Federal Health Program. International Migration \& Integration, 16, 1041-1055 
Health Canada. (2015). Canada Health Act: Annual Report, 2014-2015. Retrieved from http://www.hc-sc.gc.ca/hcs-sss/pubs/cha-lcs/2015-cha-lcs-ar-ra/index-eng.php

Heymann, J., Cassola, A., Raub, A., \& Mishra, L. (2013) Constitutional Rights to Health, Public Health, and Medical Care: The Status of Health Protections in 191 Countries. Global Public Health, 8(6), 639-653

Hoffman, M. (1989). Critical Theory and the Inter-Paradigm Debate. Journal of International Studies, 16(2), 231-250

Immigration and Refugee Protection Regulations, Statutes of Canada (2001, c. 27). Retrieved from the Department of Justice Canada website: http://laws.justice.gc.ca/PDF/I-2.5.pdf

Jackman, M. (1988). The Protection of Welfare Rights under the Charter. Ottawa Law Review, 20(2), 257-338

Lilja, M. \& Vinthagen, S. (2014). Sovereign Power, Disciplinary Power and Biopower: Resisting what Power with what Resistance? Journal of Political Power, 7(1), 107-126

Magalhaes, L., Carrasco, C., \& Gastaldo, D. (2010). Undocumented Migrants in Canada: A Scope Literature Review on Health, Access to Services, and Working Conditions. Journal of Immigrant Minority Health, 12, 132-151

McKeown, D. (2013). Medically Uninsured Residents in Toronto (Report No. 2013.HL21.5). Retrieved from the Toronto Public Health Board Website: http://www.toronto.ca/legdocs/mmis/2013/hl/bgrd/backgroundfile-57588.pdf

Miklavcic, A. (2011). Canada's Non-Status Immigrants: Negotiating Access to Health Care and Citizenship. Medical Anthropology, 30(5), 496-517

No One is Illegal-Toronto. (2004a). Sanctuary City. Retrieved from http://toronto.nooneisillegal.org/sanctuarycity

No One is Illegal-Toronto. (2004b). Access without Fear: Don't Ask Don't Tell. Retrieved from http://toronto.nooneisillegal.org/dadt

No One is Illegal-Toronto. (2015). New Report Confirms Toronto Police Racially Profile Refugees and Migrants. Retrieved from the No-One is Illegal website under End Police Brutality: http://www.toronto.nooneisillegal.org/ImmigrationsDirtyWork

Office of the United Nations High Commissioner for Human Rights (OHCHR). (1996-2016). Committee on Economic, Social, and Cultural Rights: Monitoring the Economic, Social and Cultural Rights. Retrieved from the OHCHR website under Human Rights Bodies: http://www.ohchr.org/EN/HRBodies/CESCR/Pages/CESCRIntro.aspx 
OHCR. (2008). Fact Sheet No. 31: The Right to Health. Retrieved from the OHCHR website under Fact Sheets: http://www.ohchr.org/EN/PublicationsResources/Pages/FactSheets.aspx

Olsen, C., El-Bialy, R., Mckelvie, M., Rauman, P. \& Brunger, F. (2014).”Other” Troubles: Deconstructing Perceptions and Changing Responses to Refugees in Canada. Journal of Immigrant Minority Health, 1-9

Ontario Ministry of Health and Long-Term Care. (2009). Publications: OHIP Fraud. Retrieved from http://www.health.gov.on.ca/en/public/publications/ohip/card_fraud.aspx Ontario Ministry of Health and Long-Term Care. (2011). Publications: OHIP Eligibility of Canadian-Born Children of OHIP-ineligible Parents. Retrieved from http://www.health.gov.on.ca/en/public/publications/ohip/eligibility_2.aspx

Perez-Doherty, I. (2015). Audit Report, Access T.O Initiative: FCJ Refugee Centre Reporting to the City of Toronto, Department of Social Policy, Analysis, and Research. Retrieved from the FCJ Refugee Centre website under Publications: http://www.fcjrefugeecentre.org/wpcontent/uploads/2016/02/AUDIT-REPORT-ACCESS-T.O.-INITIATIVE.pdf

Ontario Health Insurance Act, RRO 1990, Reg 552. Retrieved from the Government of Ontario website under Health Insurance Act: https://www.ontario.ca/laws/regulation/900552

Reference Re Public Service Employee Relations Act (Alberta), 1987. 1 S.C.R. 313. Retrieved from Judgements of the Supreme Court of Canada website under Supreme Court decisions: https://scc-csc.lexum.com/scc-csc/scc-csc/en/item/205/index.do

Sidhu, N. (2013). Accessing Community Programs and Services for Non-Status Immigrants in Toronto. Retrieved from the Social Planning Toronto website: http://www.socialplanningtoronto.org/category/resources/reports/

Slaight Communications Inc v. Davidson, 1989. 1 S.C.R. 1038. Retrieved from Judgements of the Supreme Court of Canada website under Supreme Court decisions: https://scccsc.lexum.com/scc-csc/scc-csc/en/item/450/index.do

Surani, N. (2013). Accreditation Canada: Better Quality. Better Health. Community Health Centres in Ontario. Retrieved from https://accreditation.ca/community-health-centres-ontario

Simich, L., Wu, F., \& Nerad, S. (2007). Status and Health Security: An Exploratory Study of Irregular Immigrants in Toronto. Canadian Journal of Public Health, 98(5), 369-373

UN Committee on Economic, Social and Cultural Rights (CESCR), UN Committee on Economic, Social and Cultural Rights: Concluding Observations, Canada. 4 March 2016, E/C.12/CAN/CO/6. Retrieved from the United Nations Human Rights Office of the High Commissioner website under Treaties: http://tbinternet.ohchr.org/Treaties/CESCR/Shared\%20Documents/CAN/E_C12_CAN_CO_6_23228_E.pdf 